\title{
BRAND PERCEPTIONS IN BANKING SERVICES AND THE EFFECTS OF SERVICE QUALITY ON PERCEIVED VALUE, CUSTOMER SATISFACTION AND LOYALTY
}

DOI: 10.17261/Pressacademia.2021.1385

JMML- V.8-ISS.1-2021(3)-p.34-52

\section{Ferudun Yayman}

Beykent University, Graduate School, Beyoglu, Istanbul, Turkey. ferudun.yayman@hotmail.com , ORCID: 0000-0002-6347-9376

\begin{tabular}{l}
\hline Date Received: December 27, $2020 \quad$ Date Accepted: March 9, 2021 \\
\hline To cite this document \\
Yayman, F. (2021). Brand perceptions in banking services and the effects of service quality on perceived value, customer satisfaction and loyalty. \\
Journal of Management, Marketing and Logistics (JMML), V.8(1), p.34-52. \\
Permanent link to this document: http://doi.org/10.17261/Pressacademia.2021.1385 \\
Copyright: Published by PressAcademia and limited licensed re-use rights only. \\
\hline
\end{tabular}

\section{ABSTRACT}

Purpose - The aim of this study is to help banks operating in the field of retail banking; To examine the effects of their image as a brand and the quality of the services they provide on customer value and customer satisfaction and loyalty.

Methodology - The research was carried out by analyzing the data compiled with the survey method among 752 retail banking customers in the SPSS program.

Findings - Research results show that brand perception and perceived service quality positively affect the customer perceived value and customer loyalty. However, according to the results obtained regarding perceived value, customer satisfaction and customer loyalty relationship, the mediating role of perceived value in the effect of brand perception and perceived service quality on customer satisfaction was confirmed. In addition, it has been determined that customer satisfaction has a mediating role in the effect of brand perception and perceived service quality on customer loyalty.

Conclusion - The results obtained within the scope of this study; With the theoretical findings revealed by academic researchers about the effects of brand perception and perceived service quality phenomena on customer value and customer loyalty process, bank managers and other practitioners should be informed about the factors that really add value to the customer and increase customer loyalty in order to provide sustainable competitive advantage in their field of activity. It offers very important information.

Keywords: Brand perceptions, perceived service quality, perceived customer value, customer satisfaction, customer loyalty JEL Codes: M30, M31, M39

\section{BANKACILIK HIZMETLERINDE MARKA ALGILARI VE HIZMET KALITESININ ALGILANAN DEĞER, MÜŞTERi TATMINI VE BAĞLILIĞINA ETKILERI}

\section{ÖZET}

Amaç- Bu çalışmanın amacı, bireysel bankacılık alanında faaliyet gösteren bankaların; birer marka olarak imajlarının ve sundukları hizmetlerin kalitesinin yarattığı müşteri değeri ile müşteri tatmini ve bağlılı̆ı üzerindeki etkilerini incelemektir.

Yöntem- Araştırma, 752 bireysel bankacılık müşterisi arasında anket yöntemi ile derlenen verilerin SPSS programında analiz edilmesi ile gerçekleştirilmiştir.

Bulgular- Araştırma sonuçları, marka algısı ve algılanan hizmet kalitesinin, müşterinin algıladığı değeri ve müşteri bağlılığını olumlu yönde etkilediğini göstermektedir. Bununla birlikte algılanan değer, müşteri tatmini ve müşteri bağlılı̆ı ilişkisine yönelik elde edilen sonuçlara göre ise, marka algısı ve algılanan hizmet kalitesinin müşteri tatminine etkisinde, algılanan değerin aracılık rolü doğrulanmıştır. Ayrıca, marka algısı ve algılanan hizmet kalitesinin müşteri bağlılı̆ına etkisinde de, müşteri tatmininin aracılık rolü olduğu saptanmıştır.

Sonuç- Bu çalışma kapsamında elde edilen sonuçlar; akademik alandaki araştırmacılara marka algısı ve algılanan hizmet kalitesi fenomenlerinin, müşteri değeri ve müşteri bağlılı̆̆ı sürecindeki etkilerinin ortaya koyduğu teorik bulgular ile banka yöneticileri ve diğer uygulayıcılara kendi faaliyet alanlarında sürdürülebilir rekabet avantajı sağlamak için, müşteriye gerçekten değer katan ve müşteri bağılığını artıran faktörlerin neler olduğunu bilmeleri konusunda oldukça önemli bilgiler sunmaktadır.

Anahtar Kelimeler: Marka algıları, algılanan hizmet kalitesi, algılanan müşteri değeri, müşteri tatmini, müşteri bağ|lığı JEL Kodları: M30, M31, M39 


\section{GíRiş}

Bankalar bir ülkedeki ekonomik ve sosyal hayatın can damarlarıdır. Günümüzde içinde bankanın olmadığı bir ekonomik faaliyet ve sosyal yaşam düşünmek çok zordur. Bankalar genel ekonomi içerisindeki faaliyetleri ile toplumun ihtiyaç duyduğu üretim ve tüketim zincirinin hemen her noktasında yer alır. Bankalar bu yönleriyle ekonominin anahtar unsuru konumundadır; çünkü güvenilir finansal hizmet sağlayıcıları olarak hem bireyler hem de işletmeler için yaşamsal hizmetler sunarlar.

Bankalar, ekonomik faaliyetleri nedeniyle işletmelerin ve bireylerin ihtiyaç duyduğu fonların sağlanmasında ve ticari hayatın düzenli bir biçimde yürütülmesinde büyük rol oynar. Bankalar bu işlevleri; aracılık yapma, kaydi para yaratma, parasal istikrarın sağlanması ve kaynakların vade değişimi gibi birtakım fonksiyonları yerine getirerek yapar. Bankaların en temel işlevi, aracılık fonksiyonudur. Bankalar, ellerinde fon fazlası olan tasarruf sahipleri ile ekonomik faaliyetlerini yürütebilmek amacıyla fon ihtiyacı olanlara aracılık eder. Yürüttükleri bu aracılık fonksiyonu ile aynı zamanda genel ekonomideki atıl fonların, finansal kaynağa ihtiyaç duyan işletmelere ya da bireylere akışını sağlayarak faaliyette bulundukları ülkenin ekonomik gelişimine ve toplumsal kalkınmasına katkıda bulunurlar. Bankaların bir ticari işletme olarak en önemli özelliği, hizmet fonksiyonlarının olmasıdır. Bankalar ekonomik faaliyetleri çerçevesinde aslında hizmet üretmektedirler. Bunu, başta bankacılık kanunu olmak üzere yasalarla belirlenmiş yetkileri dahilinde yaparlar. Bununla birlikte bankalar, birer ticari işletme olarak aynı zamanda sektörde birbirleriyle de rekabet halindedir. Her bankanın sektörde varlığını sürdürebilmesi, sunduğu ürün ve hizmetlerde fark yaratarak rekabet avantajı ve kar elde etmesine bağııdır. Bunu da ancak doğru yönetim ve stratejilerle başarabilirler.

Bankaların yönetimi esas itibariyle üç temele dayanır: Pazarlama, operasyon ve risk yönetimidir. Pazarlama, tüm stratejilerin odak noktası sayılır. Çünkü her ticari işletmede olduğu gibi bankalar için de müşteri, en temel kaynaktır. Bu kaynağın sağlanması, elde tutulması işletmenin karlıı̆̆ı ve varlığı için gereklidir. Çünkü, müşteri varsa işletme vardır. İşte bu nedenle bankaların geleceği, sahip oldukları müşteri tabanını karlı ve verimli bir biçimde büyütmelerine bağlıdır. Bunu da ancak, olumlu marka algısı ve kaliteli hizmet sunumu ile müşteri değeri yaratarak, onların tatmin olmasını ve bankaya bağı kalmalarını sağlayarak yapabilirler. Bu nedenle çalışmanın amacı, literatürde daha önce çalışması yapılmayan marka algısı ve algılanan hizmet kalitesi fenomenlerinin her ikisinin birlikte, algılanan değer, müşteri tatmini ve müşteri bağlılığı sürecindeki etkilerini ve sonuçlarını araştırmaktır.

\section{TEORIK ÇERÇEVE}

Marka, insanların "ayırt edicilik" ve "farklılık" ihtiyacından ortaya çıkmıştır. Neredeyse insanlık tarihi kadar eski olan marka ya da markalama zamanla evrimleşse de; hep aynı ihtiyacı gidermeye yönelik olarak "ayırt edilmek, farklılık ve farkındalık" işlevi üzerine inşa edilmiştir (Sağlam, 11.02.2019, www.brandingturkiye.com; Erişim Tarihi: 05.05.2020).

Literatürde markanın tanımı konusunda pek çok farklı görüş vardır. Bununla birlikte hemen her uzmanın farklı marka tanımı olsa da, genel olarak marka tanımlarının iki temel yaklaşıma dayandığı görülmektedir: Marka tanımı, bazen amaçlarına bazen de özelliklerine göre yapılmaktadır (Wood, 2000: 664). Bunun nedeni ise paydaş yaklaşımıdır. Bu bağlamda marka, tüketicilerin veya marka sahibinin bakış açısından ya da her ikisini de kapsayan bütünsel bir yaklaşımla tanımlanmaktadır (Wood, 2000: 664). Konuyla ilgili kurum ve kişilerce çok çeşitli marka tanımları yapılmıştır. Örneğin, marka ile ilgili uluslararası alanda kabul edilmiş yasal bir tanım mevcuttur: "Marka, bir ürünün veya hizmetin kaynağını belirleyen ve onu rekabetten ayıran bir işaret veya işaretlerdir" (Kapferer, 2008: 10).

Marka algısı ise, tüketici zihninde oluşan duygusal kodlardır. İnsanlar dünyayı ve çevrelerinde olup biten her şeyi duyuları aracılığıyla algılamaktadır. Algı, bireyin dünyanın anlamlı bir resmini oluşturmak için bilgi girdilerini seçtiği, düzenlediği ve yorumladığı bir süreçtir (Kotler, 1999: 94). Bir diğer ifadeyle algı, duyularımız aracılı̆̆ıyla aldığımız bilgileri zihinsel süreçlerde işleme, yorumlama ve anlamlandırma sürecidir. Bu süreçte, önceki bilgilere göre karşılaştırma ve muhakeme etme yoluyla konulan bir tanı ve hüküm vardır. Bu hüküm davranışları etkileyen, onlara yön veren özellikler içermektedir (Yüksel, 2014:54). Kişi belli bir ürün ya da hizmet satın alacağı zaman, hafızasında daha önceden kaydedilen bilgilere başvurarak zihninde var olan marka algısına göre (duygusal kısa yollar oluşturarak) kararını verir. Markanın tüketicinin zihninde oluşturduğu algı, onun karar vermesini kolaylaştırır. Çünkü insanlar zihinsel süreçlerinde duygusal kısa yolları kullanmayı tercih ederler (Kahneman, 2017: 26-27).

Dolayısıyla marka algısı, tüketicinin zihninde daha önce yaşadığı bir deneyimle gerçekleşmekte ve bu deneyim, bir tatmin duygusu ile tüketicinin algıladığı değeri artırmaktadır. Bu nedenle de tüketici zihninde o marka ile ilgili bir his oluşmakta ve bu his zihinsel süreçlere kaydedilerek tekrar tekrar başvurulmasını sağlamaktadır. Bu durum, tüketicinin karar süreçlerinde etkili olmaktadır. Marka algısı; marka imajı, işletme imajı, işletme güveni ve çalışan güveni olmak üzere dört bileşenden oluşmaktadır (Brodie vd., 2009:345-355). 
Hizmet kalitesi, müşterinin satın aldığı bir hizmetten beklediği ile algıladığını karşılaştırması sonucu oluşur. Müşterinin hizmet süreci boyunca yaşadığı deneyimler onun kalite algısını etkiler. Hizmet sürecinde kalite algısına etki eden unsurlar hizmet kalitesi belirleyicileridir (Parasuraman vd. (1985:47). Hizmet kalitesini belirleyen unsurlar ise; somut unsurlar, güvenilirlik, heveslilik, güvence ve empatidir. Somut unsurlar; fiziksel mekan, donanım (ekipman) ve personelin görünümüdür. Güvenilirlik, söz verilen hizmetin tam ve güvenilir bir şekilde sunulmasıdır. Heveslilik, müşterilere yardım etmekte istekli olunması ve hizmetin hızlı sunulmasıdır. Güvence, çalışanların bilgili ve güvenilir olmalarıdır. Empati, müşterilere kişiselleştirilmiş ilgi gösterilmesidir (Parasuraman vd., 1988:23).

Bir hizmetin algılanan kalitesi, tüketicinin hizmetten beklentileri ile hizmet sürecindeki deneyimleri sonucu oluşan yargısı arasındaki farktır. Eğer tüketicinin deneyimleri, beklentilerini karşılıyor ya da üzerindeyse algılanan kalite yüksektir; karşılamıyorsa düşüktür (Grönroos, 1984:36-44).

Literatürde, algılanan değere iki temel açıdan yaklaşılmaktadır. Bunlar "Faydacı Yaklaşım” ve "Davranışsal Yaklaşım”dır. Faydacı yaklaşım, müşterilerin, ürün veya hizmetlerin kullanımından sağladıkları fayda ile bunun karşılığında ödeyecekleri maliyet arasındaki dengeyi esas alarak ürünlere veya hizmetlere değer atfetmektedir. Diğer taraftan 'Davranışsal yaklaşım' ise, müşteri ve işletme arasındaki sosyal etkileşimlerin altını çizer ve algılanan değer, müşterinin tüketiminden veya ürün ve hizmetlerin kullanımından esinlenir (Boksberger ve Melsen, 2011: 231).

Faydacı modeller değeri, "genellikle müşterinin aldığı bir şeyin, kendisine sunulan bir teklifin sağladığı çözümün ve müşterinin bu çözümü elde etmek için katlandığı fedakarlıkların bir işlevi olarak tanımlamaktadır (Khalifa, 2004:648) Pazarlama literatüründe, Zeithaml (1988) tarafından yapılan nispeten erken dönem müşteri değeri önerisi, evrensel olarak en geniş tanımlarından biri kabul edilmektedir. Zeithaml (1988: 13) algılanan değeri, "tüketicinin neyin alındığı ve neyin verildiği algısına dayalı olarak bir ürünün faydasına ilişkin genel değerlemesi" olarak ifade eder. Zeithaml'a (1988: 14) göre; değerin fayda bileşenleri, belirgin içsel nitelikleri, dışsal nitelikleri, algılanan kaliteyi ve diğer ilgili yüksek seviyeli soyutlamaları içerir. Buna karşılık, fedakarlık bileşenleri ise, parasal ve parasal olmayan maliyetlerden oluşur.

Diğer bir yaklaşım, algılanan değerin davranışsal perspektifi ise, yapıyı daha kapsamlı bir şekilde ele alır ve onu faydacı fayda ve fedakarlıklardan daha derinlemesine açıklamaya çalışır (Boksberger ve Melsen, 2011: 231). Bu bağlamda, algılanan değerin davranışsal yönüyle ilgili olarak çok boyutlu kavramlaştırma fikrini benimseyen Sheth vd. (1991), bir "tüketim değeri teorisi" önermiştir. Geliştirdikleri teorik modelde, algılanan müşteri değerini "tüketici tercih davranışını etkileyen beş tüketim değeri" olarak tanımlamışlardır. Bunlar; işlevsel değer, sosyal değer, duygusal değer, epistemik değer ve koşullu değerdir (Sheth vd., 1991:159-170). Sheth vd.'ne (1991) göre; bir tüketici kararı, beş tüketim değerinin herhangi biri veya tümünden etkilenebilir. Benzer şekilde Woodruff (1997) da, algılanan değeri "müşterinin kullanım durumlarında müşterinin hedeflerine ve amaçlarına ulaşmasını kolaylaştıran (veya engelleyen) kullanımdan kaynaklanan bu ürün özellikleri, özellik performansları ve kullanımdan kaynaklanan sonuçlar için müşterinin algılanan tercihi ve değerlemesi” olarak tanımlar. Woodruff (1997:141). Kısacası Woodruff, değerin müşterilerin öğrenilmiş algılarından, tercihlerinden ve değerlemelerinden kaynaklandığını vurgular.

Tatmin, tüketicinin bir ürün ya da hizmetle ilgili beklentilerinin o ürün ya da hizmeti kullandıktan sonra algıladığı performans sonuçlarının yarattığı bilişsel duygulardır. Dolayısıyla bir alıının bir ürün veya hizmeti satın aldıktan sonra elde edeceği tatmin duygusu, o ürün ya da hizmetle ilgili beklentilerine bağlıdır. Eğer ürün/hizmet beklentileri karşılıyorsa tatmine, karşılamıyorsa tatminsizliğe yol açar. Hatta satın alınan ürün ya da hizmetten elde edilen performans beklentilerin üzerindeyse, tatmin düzeyi daha da artar (Yükselen, 2017:26).

Müşteri tatmini, işletmeler açısından uzun vadeli ilişki yaratmak ve faaliyette bulundukları sektörde rekabet edebilmeleri için en önemli ve öncelikli konudur. Bu bakımdan müşteri tatmini, hizmet sektöründe yer alan bankaların başarılarında anahtar rol oynamaktadır.

Müşteri bağııı̆̆ı, müşterilerin tekrar satın alma davranışlarına en yakın adım olarak tanımlanmaktadır (Minh ve Huu, 2016:104). Bu bakımdan müşteri bağıılığı, bir müşterinin bir hizmet / ürün sağlayıcısıyla sahip olduğu tüm deneyimlerin bir sonucu olarak ifade edilir (Masceranhas vd., 2006:399). Oliver (1999: 34) müşteri bağlıı̆ını "tercih edilen bir ürünü / hizmeti gelecekte tutarlı bir şekilde yeniden satın alma veya yeniden tanıtma, böylece durumsal etkilere ve değiştirme davranışına neden olma potansiyeline sahip pazarlama çabalarına rağmen, aynı marka veya aynı marka setinin tekrar tekrar satın alınmasına neden olma konusunda derin bir bağlıık" olarak tanımlamaktadır (Masceranhas vd., 2006:399). Müşteri bağlılı̆ının işletmelerin nihai performansları üzerinde önemli ölçüde etkisi bulunmaktadır (Hessket vd. (2008:14). https://hbr.org/2008/07/putting-the-serviceprofit-chain-to-work (Erişim Tarihi: 08.12.2020). 


\section{ARAŞTIRMA YÖNTEMI VE VERILERIN ANALIZi}

\subsection{Araştırmanın Amacı ve Yöntemi}

Bu çalışmanın amacı, bankacılık sektöründe faaliyet gösteren bankaların, bir marka olarak imajlarının ve sundukları hizmetlerin kalitesinin, müşteride yarattığı değer algısı ile oluşan müşteri tatmininin yarattığı bağlılık üzerindeki etkisini araştırmaktır. Bu amaç doğrultusunda literatürde yer alan çalışmalardan yararlanılarak Şekil 1'deki kavramsal model geliştirilmiştir.

\section{Şekil 1: Araştırmanın Kavramsal Modeli}

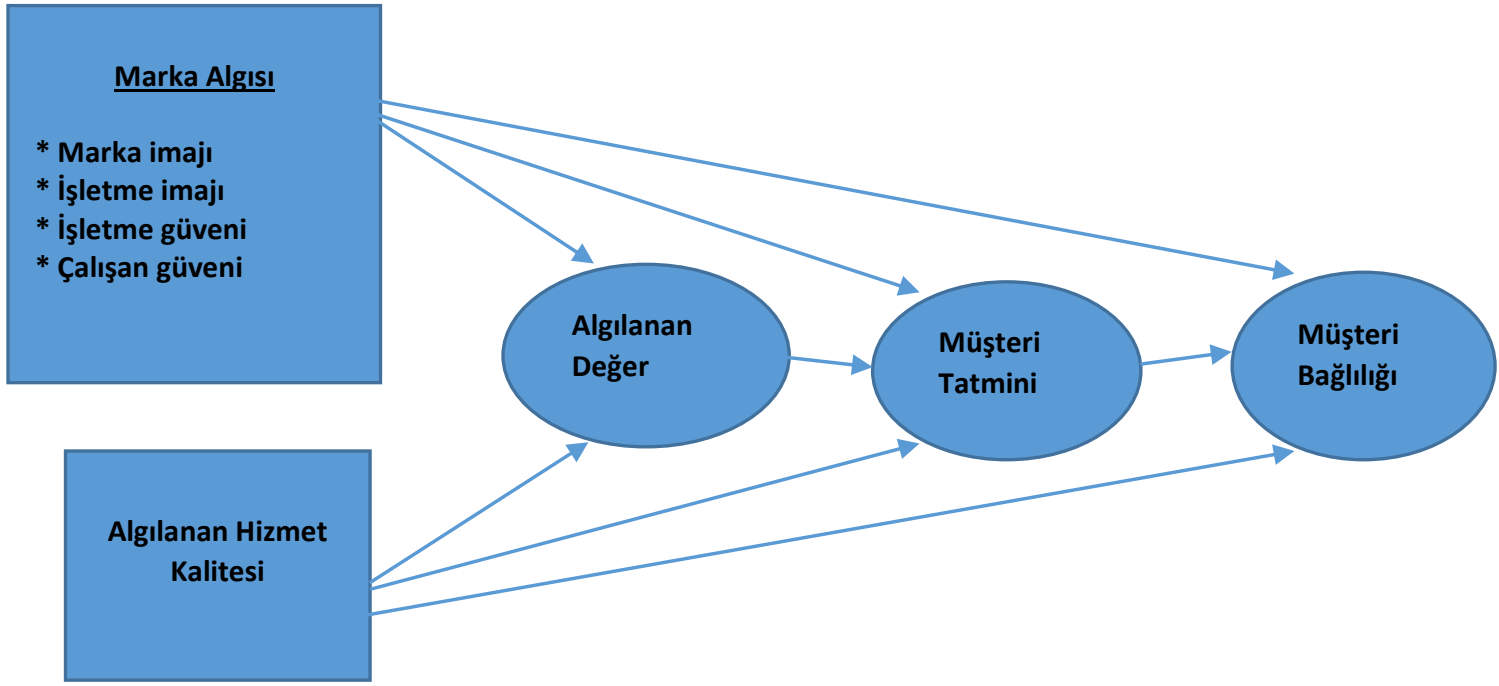

Araştırmanın ana kütlesini, Tekirdağ ilinde yaşayan 18 yaşından büyük bireysel bankacılık hizmetlerini alan müşteriler oluşturmaktadır. Araştırmada veri toplama yöntemi olarak "anket yöntemi" kullanılmıştır. Kavramsal modelde belirtilen değişkenler ile ilgili literatürde (Brodie vd., 2009; El-Adly, 2018) yer alan soru maddeleri kullanılarak bir anket formu oluşturulmuştur. Araştırma öncesi, ilgili anket formu 10 kişilik bireysel bankacılık müşterisi üzerinde ön teste tabi tutulmuş olup herhangi bir değişiklik ihtiyacı görülmemiştir. Araştırmaya ilişkin veriler, 752 kişiyle yüz yüze yapılan ve toplam 50 adet sorunun yer aldığı anketlerden elde edilmiştir. Katılımcıların anket sorularını, bireysel bankacılık işlemlerinde en çok kullandıkları bankanın hizmetlerini göz önünde bulundurarak cevaplandırmaları istenmiştir. Elde edilen sonuçlar SPSS programında analiz edilmiştir.

\subsection{Araştırma Hipotezleri}

\subsubsection{Marka Algısının Algılanan Değer, Tatmin ve Müşteri Bağıılığına Etkisi}

Araştırmada marka algısının algılanan müşteri değeri - tatmin ve bağlılık süreci üzerindeki etkilerine yönelik araştırma hipotezleri belirlenirken, Brodie vd.'nin (2009:353-354) hizmet perspektifinden markalaşmanın teorik ve pratik olarak daha iyi anlaşılmasına yönelik müşterilerin marka algılarının müşteri değeri-sadakat sürecini nasıl etkilediği ile ilgili yaptıkları çalışma sonuçlarından yararlanılmıştır. Bu çalışmada "marka algısı" kavramı, aynı zamanda marka imajı, işletme imajı, işletme ve çalışan güveni kavramlarını içermektedir. Dolayısıyla, marka algısını oluşturan bu unsurlar, markanın tüm yönlerinin müşterilerin değer algıları üzerindeki etkileri hakkında bize fikir vermekte ve teorik çerçevenin kullanımını desteklemek için deneysel kanıtlar sunduğunu göstermektedir. Bu çerçevede hipotezler şu şekilde belirlenmiştir:

H1: Marka algısı ve algılanan hizmet kalitesi, müşterinin algıladığı değeri olumlu yönde etkilemektedir.

H2: Marka algısının müşteri tatminine etkisinde, algılanan değerin aracılık rolü vardır.

H3: Marka algısının müşteri tatminine etkisinde, algılanan değerin kolaylaştırıcı etkisi vardır.

H4: Marka algısının müşteri bağııığına etkisinde, müşteri tatmininin aracılık rolü vardır. 


\subsubsection{Algılanan Hizmet Kalitesinin Algılanan Değer, Tatmin ve Müșteri Bağlılığına Etkisi}

Bir hizmetin algılanan kalitesi, tüketicinin hizmetten beklentileri ile hizmet sürecindeki deneyimleri sonucu oluşan yargısı arasındaki farktır. Eğer tüketicinin deneyimleri, beklentilerini karşılıyor ya da üzerindeyse algılanan kalite yüksektir; karşılamıyorsa düşüktür (Grönroos, 1984:36-44). Dolayısıyla, hizmet kalitesi, müşterinin satın aldığı bir hizmetten beklediği ile algıladığını karşılaştırması sonucu oluşur. Müşterinin hizmet süreci boyunca yaşadığı deneyimler onun kalite algısını etkiler. Hizmet sürecinde kalite algısına etki eden unsurlar ise hizmet kalitesinin belirleyicileridir. Parasuraman vd. (1988) hizmet kalitesinin ölçümüyle ilgili yaptıkları (SERVQUAL) çalışmada hizmet kalitesi unsurlarını; somut unsurlar, güvenilirlik, heveslilik, güvence ve empati olmak üzere beş boyutta toplamışlardır (Parasuraman vd., 1988:23). Somut unsurlar; fiziksel mekan, donanım (ekipman) ve personelin görünümüdür. Güvenilirlik, söz verilen hizmetin tam ve güvenilir bir şekilde sunulmasıdır. Heveslilik, müşterilere yardım etmekte istekli olunması ve hizmetin hızlı sunulmasıdır. Güvence, çalışanların bilgili ve güvenilir olmalarıdır. Empati, müşterilere kişiselleştirilmiş ilgi gösterilmesidir (Parasuraman vd., 1988:23).

Müşteri bağlılığına yol açan faktörler, esas olarak ya müşterilerin hizmet kalitesi ve müşteri tatmini gibi hizmete ilişkin sonraki algılarından kaynaklanan değerlendirmeleri ya da güven ve bağlıık gibi tekrarlanan hizmet işlemlerinin ilişkisel sonuçları kategorisine girenlerdir (Rai ve Medha, 2013:152). Bu nedenle hizmet kalitesi, müşteriler için büyük önem taşımaktadır. Çünkü müşteriler, hizmeti, hizmet personelinin niteliklerine ve bir hizmet işletmesinin özelliklerine göre algılar. Hizmet personelinin müşteri odaklı özellikleri, hizmet sağlayıcıların yumuşak kalite özelliklerini yansıtan güvenilirlik, duyarlılık, güvence ve empatidir (Zeithaml ve Bitner, 2000). Bu niteliklere dayalı olarak müşteriler ve çalışanlar arasındaki olumlu kişilerarası etkileşimler müşteri memnuniyetini artırabilir (Hartline vd., 2000; Parasuraman vd., 1985). Güvenilirlik, çalışanların müşteri ihtiyaçlarına tutarlı bir şekilde yanıt vermesine ve son teslim tarihlerini karşılamasına yardımcı olur. Hızlı yanıt verme ve güvenceye sahip çalışanlar, şirketin ürünleri, hizmetleri ve müşterilerin ihtiyaçları hakkında daha fazla bilgiye sahiptir. Empati, çalışanlar ve müşteriler arasındaki iletişim sürecini iyileştirmeye yardımcı olur (Lenka vd., 2009:48-49).

Hindistan ticari bankalarının hizmet kalitesinin, müşteri bağlılığını teşvik eden müşteri tatminini artırıp artırmadığını inceleyen Lenka vd. (2009), hizmet kalitesinin insani, teknik ve somut yönlerinin iyileştirilmesinin müşteri tatminini artırdığını ortaya koymuştur. Söz konusu çalışmada, hizmet kalitesinin insani yönlerinin, teknik ve somut yönlere kıyasla müşteri tatminini daha güçlü bir şekilde etkilediği bulunmuştur. Bu nedenle, fiziksel çevrenin müşterinin hizmet kalitesi algısı üzerinde olumlu etkisinin olabileceği ve buna göre banka hizmetlerinin insani, teknik ve somut yönlerinin daha iyi olması, müşterilerin tatmin düzeyini artıracağı öne sürülmektedir (Lenka vd., 2009:59). Lenka vd.'ne (2009) göre, hizmet kalitesi, hizmetlerin yönetimsel sunumu iken; tatmin ise, müşterilerin bu hizmetlerle ilgili deneyimleridir. Dolayısıyla İyileştirilmiş hizmet kalitesi, daha fazla müşteri tatmini ve bağlıı̆̆ı ile sonuçlanmaktadır (Lenka vd., 2009:50). Hizmet kalitesi ile müşteri bağlılığı sürecine yönelik olarak Kheng vd. (2010) tarafından yapılan diğer bir çalışmada, Malezya bankalarında sunulan bankacılık hizmet kalitesinin müşteri bağlılı̆̆ı üzerine etkisi incelenerek, hizmet kalitesi boyutları (somut, güvenilirlik, duyarlılık, empati ve güvence) ile müşteri bağlıl̆ğ arasındaki ilişkilerde müşteri tatmininin aracılık etkisi olduğu bulunmuştur (Kheng vd.,2010:62).

Minh ve Huu (2016:110) da, bireysel bankacılık müşterileri arasında yaptıkları bir araştırmada, hizmet kalitesinin müşteri tatmininin; müşteri tatminin de müşteri bağıılı̆ının bir öncülü olduğunu bulmuşlardır. Ayrıca, hizmet kalitesi ile müşteri bağlılı̆ı arasında pozitif bir ilişki olduğunu ve müşteri tatminin, hizmet kalitesi ile müşteri bağlılığı arasında kısmen aracılık ettiğini de doğrulamışlardır. Farklı bir çalışmada, Caruana (2002:821), müşteri tatmininin aracılık rolünü üstlenerek hizmet kalitesinin bağlılık üzerindeki etkisini incelemiştir. Bireysel bankacılık müşterileri arasında yapılan araştırmada elde edilen sonuçlar, müşteri tatmini yoluyla hizmet kalitesinin müşteri bağlılığı üzerine aracı bir rol oynadığı iddiasına destek sağlayarak katkıda bulunmuştur. Araştırmada ayrıca, hizmet kalitesinin müşteri tatmini için önemli bir girdi olduğu görülmüştür. Benzer bir biçimde, Mosahab vd. (2010:72) de, hizmet kalitesinin müşteri tatmini yoluyla hem doğrudan hem de dolaylı olarak müşteri bağlılı̆ı üzerinde etkisi olduğunu bulmuştur. Konuyla ilgili yapılan bir başka çalışmada ise, Rai ve Medha (2013:153) hayat sigortası müşterileri üzerine yaptıkları bir araştırmada, müşteri bağııı̆̆ açısından hizmet kalitesinin birinci derecede önemli faktör olduğunu bulmuşlardır. Bir diğer çalışmada, internet bankacılığı hizmet kalitesi, e-müşteri memnuniyeti ve e-müşteri sadakati arasındaki ilişkinin önemli olduğu ortaya konmuştur (Amin, 2016:280). Velosa vd. (2018:497) de, Portekiz perakende sektöründe yaptıkları bir araştırmada, hizmet kalitesinin müşteri tatmininin ana belirleyicisi olduğunu ortaya koymuşlardır. Ayrıca müşteri tatmini ve hizmet kalitesinin müşteri bağııı̆ını önemli ölçüde etkilediğini bulmuşlardır. Benzer biçimde Al-Tit'in (2015:129) yaptığı bir çalışmada, hizmet kalitesinin müşteri tatmini ve müşteriyi elde tutma üzerinde olumlu bir etkiye sahip olduğu; ayrıca, müşteri tatmininin hizmet kalitesi ile müşteriyi elde tutma arasındaki ilişkiye aracı olduğu doğrulanmıştır. Yapılan araştırmalarda elde edilen sonuçlar, hizmet karşılaşmasının, müşterilerin tatmin ve bağlılı̆ında önemli rol oynadığını göstermektedir (Arora ve Narula, 2018:33). Araştırmaların çoğu, kaliteli hizmet veren bir işletmenin kesinlikle memnun müşterilere sahip olacağını ve dolayısıyla memnun müşterilerin de bağıı olacağını göstermektedir. 
Bununla birlikte, algılanan hizmet kalitesinin algılanan müşteri değerine etkisinde; Cronin vd.'nin (1997:383-384) yaptığı bir araştırmada, algılanan hizmet kalitesinin algılanan müşteri değerini olumlu yönde etkilediği öne sürülmektedir. Cretu ve Brodie (2007: 236) de yaptıkları araştırmada algılanan hizmet kalitesinin algılanan müşteri değerini pozitif yönde etkilediğini bulmuşlardır. Benzer şekilde, Parasuraman ve Grewal (2000: 168-174) da, hizmet kalitesinin, algılanan müşteri değerini artırdığını söylemişlerdir. Bir başka çalışmada, Sweeney vd. (1999:99), perakende hizmet kalitesinin, tüketici değer algılarının yaratılmasında önemli bir rol oynadığını bulmuşlardır. Benzer şekilde, Sweeney ve Soutar (2001:203-220), müşterinin algılanan değerini ölçmek için PERVAL olarak adlandırdıkları fonksiyonel değer (fiyat ve kalite) ile sosyal ve duygusal değerden oluşan dört boyutlu ölçek çalışmalarında, hizmet kalitesinin algılanan değerin oluşmasında önemli rolünün olduğunu iddia etmektedirler. Literatürde yer alan bu değerlemeler ışı̆̆ında aşağıdaki hipotezler kurulmuştur:

H5: Algılanan hizmet kalitesinin müşteri tatminine etkisinde, algılanan değerin aracılık rolü vardır.

H6: Algılanan hizmet kalitesinin müşteri tatminine etkisinde, algılanan değerin kolaylaştırıcı etkisi vardır.

H7: Algılanan hizmet kalitesinin müşteri bağlılığına etkisinde, müşteri tatmininin aracılık rolü vardır.

H8: Marka algısı ve algılanan hizmet kalitesi, müşteri bağlılı̆ını olumlu yönde etkiler.

\subsubsection{Algılanan Değer, Müşteri Tatmini ve Müşteri Bağlılı̆̆ illişkisi}

Finansal hizmetler pazarı ya da daha spesifik olarak bankacılık sektöründe algılanan değer, müşteri tatmini ve müşteri bağlılı̆ı arasındaki ilişkiler, yarattıkları sonuçlar itibariyle sürdürülebilir büyüme ve rekabet avantajı açısından oldukça önemlidir. Algılanan değer, tüketicinin neyin alındığı ve neyin verildiğine ilişkin algılarına dayalı olarak bir ürünün faydasına ilişkin genel değerlemesidir (Zeithaml, 1988:14). Bu algılar tipik olarak müşterinin aldığı (örneğin kalite, faydalar, değer) ile bir ürünü almak ve kullanmak için vazgeçtikleri (örneğin fiyat, fedakarlıklar) arasında bir değiş tokuşu içerir (Woodruff, 1997:141). Müşteri tatmini genel olarak, bir ürünle ilgili bir veya daha fazla kullanım deneyiminin değerlenmesine yanıt olarak müşterinin duygularıdır (Woodruff, 1997: 143). Müşteri bağlılığı ise, bir müşterinin bir hizmet / ürün sağlayıcısıyla sahip olduğu tüm deneyimlerin bir sonucu olarak ifade edilir (Masceranhas vd., 2006:399).

Algılanan değer kavramı, müşteri tatmini ile güçlü bir ilişkisi olduğunu göstermektedir. Her iki kavram da ürünler hakkındaki değerleyici yargıları tanımlar ve her ikisi de kullanım durumuna özel önem verir (Woodruff, 1997: 143). Bu bağlamda Woodruff (1997), algılanan değerin, tüketicilerin sağlayıcılarıyla ilişkisel alışverişe ilişkin bilişsel algısını temsil ettiğini ve tatminin, tüketici tarafından algılanan değerden türetilen genel duyguyu yansıttığını ileri sürmektedir (Roig vd., 2009:777). Tatminin genellikle tüketicinin algıladığı değer tarafından belirlendiği düşünülmektedir. Bununla birlikte tatmin, çoğu kez bağılığın önemli bir belirleyicisi olarak görülmüştür (Dick ve Basu, 1994:104). Yalnız bu konuda ampirik kanıtlar biraz karışıktır. Çünkü bazı araştırmalar müşteri tatmini ve bağlılı̆ı arasında güçlü bir bağlantı sağlayamamaktadır (örneğin, Khatibi vd., 2002; Stoel vd, 2004). Bazıları da, tatmin - bağlıık ilişkisinin dolaylı ve karmaşık olduğunu belirtmektedir (örneğin, Anderson ve Mittal, 2000; Magi, 2003). Ancak karışık bir takım bulgulara rağmen, müşterilerin bağlıığını kazanmada tatminin öncü rol oynadığı birçok çalışma da yer almaktadır (Bloemer vd., 1999; Cronin vd., 2000; Eggert ve Ulaga, 2002; Hellier vd., 2003; Hennig vd., 2002; Host ve Knie-Andersen, 2004; Oliver, 1999; Yang ve Peterson, 2004'den Akt. Roig vd., 2009:778). Bu çalışmaların yanında ayrıca, Patterson ve Spreng (1997:429), Yang ve Peterson (2004:814) ve Roig vd. (2009:783) tarafından, algılanan değerin tatmin yoluyla bağlılık üzerinde dolaylı bir etkiye ve aynı zamanda bağııık üzerinde de doğrudan bir etkiye sahip olduğu bulunmuştur. Çinli mobil iletişim şirketinde yaptıkları araştırmada, Lai vd. (2009:985) de algılanan değer ve müşteri tatmininin, müşteri bağlılığının doğrudan belirleyicileri olduğunu bulmuşlardır (Lai vd., 2009: 985).

Bu çerçevede söz konusu değişkenlerin ilişkileri, aracılık rolleri ve modeldeki konumlarının cevaplayıcıların demografik özelliklerine göre farklılıkları değerlenmek üzere aşağıdaki hipotezler kurulmuştur:

H9: Marka algısı ve algılanan hizmet kalitesinin algılanan değere etkisi, yaş gruplarına göre farklıdır.

H10: Marka algısı ve algılanan hizmet kalitesinin algılanan değere etkisi, cinsiyete göre farklıdır.

H11: Marka algısı ve algılanan hizmet kalitesinin algılanan değere etkisi, öğrenim durumuna göre farklıdır.

H12: Algılanan değerin müşteri tatminine etkisi, yaş gruplarına göre farklıdır.

H13: Algılanan değerin müşteri tatminine etkisi, cinsiyete göre farklıdır.

H14: Algılanan değerin müşteri tatminine etkisi, öğrenim durumuna göre farklıdır. 
H15: Müşteri tatmininin müşteri bağlılığına etkisi, yaş gruplarına göre farklıdır.

H16: Müşteri tatmininin müşteri bağlıığına etkisi, cinsiyete göre farklıdır.

H17: Müşteri tatmininin müşteri bağlılığına etkisi, öğrenim durumuna göre farklıdır.

\subsubsection{Cevaplayıcılara İlişkin Tanımlayıcı Bilgiler}

Verilerin elde edildiği ankete cevap veren katılımcılar, demografik özellikleri itibariyle yaş, cinsiyet ve öğrenim durumlarına göre gruplandırılmış olup, dağılımlar aşağıdaki tablolarda yer almaktadır. Tablo 1'de görüleceği üzere, anketi cevaplayanların yarısını 18-30 yaş aralığındaki katılımcılar oluşturmaktadır. Cinsiyete göre dağılımda erkek cevaplayıcıların kadınlara göre daha fazla olduğu, öğrenim durumuna bakıldığında ise, cevap verenlerin çoğunluğunun (yaklaşık yüzde 70) üniversite ve üstü öğrenime sahip oldukları görülmektedir.

Tablo 1: Cevaplayıcıların Demografik Dağılımı

\begin{tabular}{|l|c|c|}
\hline Yaş Grubu & $\mathbf{n}$ & $\mathbf{\%}$ \\
\hline $18-30$ & 376 & 50 \\
\hline $31-40$ & 184 & 24,5 \\
\hline $41-50$ & 119 & 15,8 \\
\hline 51 ve üstü & 73 & 9,7 \\
\hline Cinsiyet & & \\
\hline Kadın & 338 & 44,9 \\
\hline Erkek & 414 & 55,1 \\
\hline Eğitim Durumu & & \\
\hline İlköğretim & 47 & 6,3 \\
\hline Lise & 184 & 24,5 \\
\hline Üniversite ve üstü & 521 & 69,3 \\
\hline Toplam & $\mathbf{7 5 2}$ & $\mathbf{1 0 0}$ \\
\hline
\end{tabular}

\subsubsection{Değişkenlere Iilişkin Faktör ve Güvenilirlik Analizi}

Marka algısı değişkenini oluşturan ölçek, dört farklı kavram ve on yedi soru maddesinden oluşmaktadır. Veri setinin bu dört alt değişkene dağılıp dağılmadığına ilişkin olarak faktör analizi yapılmıştır. KMO değeri 0,944, Bartlett's Testini veren Ki-Kare değeri 7105,929 olup, \%1 önem derecesinde veri setinin analiz için yeterli olduğu, örnek büyüklüğünün de uygun olduğu görülmüştür. Asal Bileşenler Yöntemi ve Varimax rotasyonu ile veri setinin dört faktöre dağılımı yapılmış olup, rotasyona tabi tutulan matris Tablo 2'de gösterilmiştir. Faktör yükleri 0,50'nin altında olan iki soru maddesi FG3 ve FG4 değerleme dışında tutulmuş olup ölçek dört faktör ve 15 soru maddesi ile somutlaşmıştır.

Tablo 2: Marka Algısı Değişkenine iliş̧kin Rotasyona Tabi Tutulmuş Faktör Matrisi

\begin{tabular}{|c|c|c|c|c|}
\hline & F1 & F2 & F3 & F4 \\
\hline $\mathrm{M} 1$ & & & 0.831 & \\
\hline $\mathrm{M} 2$ & & & 0.720 & \\
\hline $\mathrm{M} 3$ & & & 0.729 & \\
\hline $\mathrm{M} 4$ & & & 0.568 & \\
\hline $\mathrm{FI1}$ & & 0.661 & & \\
\hline $\mathrm{FI} 2$ & & 0.534 & & \\
\hline $\mathrm{FI}$ & & 0.783 & & \\
\hline $\mathrm{FI} 4$ & & 0.731 & & \\
\hline $\mathrm{FI} 5$ & & 0.504 & & \\
\hline $\mathrm{FG1}$ & & & & 0.789 \\
\hline
\end{tabular}




\begin{tabular}{|l|l|l|l|l|} 
FG2 & & & & 0.643 \\
\hline CG1 & 0.762 & & & \\
\hline CG2 & 0.771 & & & \\
\hline CG3 & 0.751 & & & \\
\hline CG4 & 0.742 & & & \\
\hline
\end{tabular}

MI: Marka imajı FI: Firma İmajı FG: Firma Güveni CG: Çalışan Güveni

Algılanan hizmet kalitesi değişkenini oluşturan ölçek, beş farklı kavram ve yirmi iki soru maddesinden oluşmaktadır. Veri setinin bu beş alt değişkene dağılıp dağılmadığına ilişkin olarak faktör analizi yapılmıştır. KMO değeri 0,953, Bartlett's Testini veren KiKare değeri 10125,734 olup, \%1 önem derecesinde veri setinin analiz için yeterli olduğu, örnek büyüklüğünün de uygun olduğu görülmüştür. Asal Bileşenler Yöntemi ve Varimax rotasyonu ile veri setinin beş faktöre dağılımı yapılmış olup, rotasyona tabi tutulan matris Tablo 3'de gösterilmiştir. Faktör yükleri 0,50'nin altında olan iki soru maddesi AGU1 ve AEM3 değerleme dışında tutulmuş olup ölçek beş faktör ve 20 soru maddesi ile somutlaşmıştır.

Tablo 3: Algılanan Hizmet Kalitesi Değişkenine i̇lişkin Rotasyona Tabi Tutulmuş Faktör Matrisi

\begin{tabular}{|c|c|c|c|c|c|}
\hline & F1 & F2 & F3 & F4 & F5 \\
\hline AFV1 & &, 762 & & & \\
\hline AFV2 & &, 779 & & & \\
\hline AFV3 & &, 678 & & & \\
\hline AFV4 & &, 699 & & & \\
\hline AGU2 &, 665 & & & & \\
\hline AGU3 &, 759 & & & & \\
\hline AGU4 &, 749 & & & & \\
\hline AGU5 &, 689 & & & & \\
\hline AH1 &, 690 & & & & \\
\hline AH2 &, 570 & & & & \\
\hline AH3 & & &, 579 & & \\
\hline AH4 & & &, 691 & & \\
\hline AEM1 & & &, 718 & & \\
\hline AEM2 & & &, 705 & & \\
\hline AEM4 & & & & &, 717 \\
\hline AEM5 & & & & &, 773 \\
\hline AGN1 & & & &, 667 & \\
\hline AGN2 & & & &, 659 & \\
\hline AGN3 & & & &, 784 & \\
\hline AGN4 & & & &, 704 & \\
\hline
\end{tabular}

Modelde yer alan değişkenlerin güvenilirlik analizleri Cronbach’s Alpha ile yapılmıştır. Analiz sonuçları aşağıdaki tabloda yer almaktadır. Tabloda görüldüğü gibi, tüm değişkenlerin yüksek güvenilirlik düzeyine sahip olduğu görülmektedir.

Tablo 4: Model Değişkenlerinin Güvenilirlik Analizi Sonuçları

\begin{tabular}{|l|c|c|}
\hline Değişkenler & Soru Sayısı & Cronbach's Alpha \\
\hline Marka Algısı & 15 & 0,924 \\
\hline *Marka İmajı & 4 & 0,853 \\
\hline *Firma imajı & 5 & 0,847 \\
\hline *Firma Güveni & 2 & 0,715 \\
\hline
\end{tabular}




\begin{tabular}{|l|c|c|}
\hline${ }^{*}$ Çalışana güven & 4 & 0,845 \\
\hline Algılanan Hiz. Kalitesi & 20 & 0,940 \\
\hline${ }^{*}$ Fiziksel varlıklar & 4 & 0,806 \\
\hline${ }^{*}$ Güvenilirlik & 6 & 0,895 \\
\hline${ }^{*}$ Heveslilik & 4 & 0,863 \\
\hline${ }^{*}$ Empati & 2 & 0,753 \\
\hline${ }^{*}$ Güven & 4 & 0,854 \\
\hline Algılanan Değer & 2 & 0,868 \\
\hline Müşteri Tatmini & 3 & 0,782 \\
\hline Müşteri Bağıı̆ığı & 3 & 0,898 \\
\hline
\end{tabular}

\subsection{Değişkenler Arasındaki iliş̧kilerin Analizi}

\subsubsection{Marka Algısı ve Algılanan Hizmet Kalitesinin Algılanan Değere Etkisinin Analizi Sonuçları}

Dört bileşenden oluşan “Marka Algısı" ile beş bileşenden oluşan “Algılanan Hizmet Kalitesi” değişkenlerinin Algılanan Değer’e etkisi, çoklu regresyon analizi ile yapılmıştır. Illk aşamada marka algısı ve algılanan hizmet kalitesi, bileşenlerinin toplamı olarak analize alınmıştır. Tablo 6'ya göre model yüzde 1 önem derecesinde anlamlı çıkmıştır. Tablo 5'e göre Marka Algısı ve Algılanan Hizmet Kalitesi ile Algılanan Değer arasındaki korelasyon katsayısı $R=0,336$ olup, ilişkinin zayıf olduğu anlaşılmaktadır. Nitekim iki değişken Algılanan Değerin yüzde 11,1'ini açıklamaktadır. Modelin katsayıları ve eşdoğrusallık değerleri Tablo 7'de gösterilmiştir. Bu sonuçlara göre $\mathrm{H} 1$ hipotezi kabul edilmiştir. Ancak, marka algııının algılanan değere etkisinin \%5,8 önem derecesinde anlamlı olduğu görülmektedir.

Tablo 5: Marka Algısı ve Algılanan Hizmet Kalitesinin Algılanan Değere Etkisine ilişskin Çoklu Regresyon Model İstatistikleri

\begin{tabular}{|c|c|c|c|c|}
\hline Model & $\mathbf{R}$ & $\mathbf{R}^{\mathbf{2}}$ & Düzeltilmiş $\mathbf{R}^{\mathbf{2}}$ & Tahminin Standart Hatası \\
\hline 1 &, 336 &, 113 &, 111 & 1,504 \\
\hline
\end{tabular}

Tablo 6: Marka Algısı İle Algılanan Hizmet Kalitesinin Algılanan Değere Etkisine iliş̧kin Çoklu Regresyon Modeli ANOVA Sonuçları

\begin{tabular}{|l|c|c|c|c|c|}
\hline Model & $\begin{array}{c}\text { Karelerin } \\
\text { Toplamı }\end{array}$ & $\begin{array}{c}\text { Serbestlik } \\
\text { Derecesi }\end{array}$ & $\begin{array}{c}\text { Karelerin } \\
\text { Ortalaması }\end{array}$ & $\mathbf{F}$ & $\mathbf{p}$ \\
\hline Regresyon & 215,598 & 2 & 107,799 & 47,662 &, 000 \\
Artık & 1694,056 & 749 & 2,262 & & \\
Toplam & 1909,654 & 751 & & & \\
\hline
\end{tabular}

Tablo 7: Marka Algısı ve Algılanan Hizmet Kalitesinin Algılanan Değere Etkisine İlişkin Çoklu Regresyon Modeli Katsayıları

\begin{tabular}{|c|c|c|c|c|c|c|c|}
\hline Model & \multicolumn{2}{|c|}{ Katsayılar } & \multirow{2}{*}{$\begin{array}{c}\begin{array}{c}\text { Standardize } \\
\text { Katsayılar }\end{array} \\
\text { Beta }\end{array}$} & \multirow[b]{2}{*}{$\mathbf{t}$} & \multirow[b]{2}{*}{$\mathbf{p}$} & \multicolumn{2}{|c|}{ Eş Doğrusallık } \\
\hline & B & Standart Hata & & & & Tolerans & VIF \\
\hline Sabit & ,578 & 329 & & 1,758 & ,079 & & \\
\hline MA & ,234 & 123 & ,099 & 1,899 & ,058 & ,435 & 2,298 \\
\hline AHK & 605 & 124 & 255 & 4,890 & ,000 & ,435 & 2,298 \\
\hline
\end{tabular}

MA: Marka Algısi; AHK: Algılanan Hizmet Kalitesi

Marka Algısı ve Algılanan Hizmet Kalitesi bileşenleri ile birlikte çoklu regresyon analizine alındığında elde edilen sonuçlar, Tablo 8 , 9 ve 10'da gösterilmiştir. Tablo 9'a göre dokuz bağımsız değişkenin bağımlı değişkene etkisini gösteren model anlamlı çıkmış olup, Marka Algısı ve Algılanan Hizmet Kalitesine ilişkin toplam dokuz alt bileşen ile Algılanan Değer arasındaki korelasyon katsayısı Tablo 8'de görüldüğü üzere 0,366 çıkmıştır. Regresyon modeli katsayılarının yer aldığı Tablo 10'a göre Marka Algısı bileşenlerinden; 
"Marka İmajı" yüzde 5; Algılanan Hizmet Kalitesi bileşenlerinden "güvenilirlik" ve "güven" \%1 önem derecesinde bu etkide rol oynamışlardır.

Tablo 8: Marka Algısı ve Algılanan Hizmet Kalitesi Bileşenlerinin Algılanan Değere Etkisine îlişkin Çoklu Regresyon Model İstatistikleri

\begin{tabular}{|c|c|c|c|c|}
\hline Model & $\mathbf{R}$ & $\mathbf{R}^{\mathbf{2}}$ & Düzeltilmiş $\mathbf{R}^{\mathbf{2}}$ & Tahminin Standart Hatası \\
\hline 1 &, 366 &, 134 &, 123 & 1,493 \\
\hline
\end{tabular}

Tablo 9. Marka Algısı ve Algılanan Hizmet Kalitesi Bileşenlerinin Algılanan Değere Etkisine İlişkin Çoklu Regresyon Model ANOVA Sonuçları

\begin{tabular}{|l|c|c|c|c|c|}
\hline Model & Karelerin Toplamı & Serbestlik Derecesi & Karelerin Ort. & $\mathbf{F}$ & $\mathbf{p}$ \\
\hline Regresyon & 255,699 & 9 & 28,411 & 12,746 &, 000 \\
\hline Artık & 1653,955 & 742 & 2,229 & & \\
\hline Toplam & 1909,654 & 751 & & & \\
\hline
\end{tabular}

Tablo 10: Marka Algısı ve Algılanan Hizmet Kalitesi Bileşenlerinin Algılanan Değere Etkisine iliş̧kin Çoklu Regresyon Modeli Katsayıları

\begin{tabular}{|c|c|c|c|c|c|c|c|}
\hline \multirow[t]{2}{*}{ Model } & \multicolumn{2}{|c|}{$\begin{array}{c}\text { Standardize Olmayan } \\
\text { Katsayılar }\end{array}$} & \multirow{2}{*}{\begin{tabular}{|c|}
$\begin{array}{l}\text { Standardize } \\
\text { Katsayılar }\end{array}$ \\
Beta
\end{tabular}} & \multirow[b]{2}{*}{$\mathbf{t}$} & \multirow[b]{2}{*}{$\mathbf{p}$} & \multicolumn{2}{|c|}{ Eş Doğrusallık } \\
\hline & B & $\begin{array}{c}\text { Standart } \\
\text { Hata }\end{array}$ & & & & Tolerans & VIF \\
\hline Sabit & ,716 & ,357 & & 2,006 & ,045 & & \\
\hline $\mathrm{MI}$ & ,231 & ,096 & 125 & 2,399 & ,017 & ,428 & 2,334 \\
\hline $\mathrm{FI}$ & ,016 & 109 & ,008 & 149 & ,881 & ,382 & 2,615 \\
\hline FG &,- 126 & 100 &,- 064 & $-1,258$ & 209 & ,458 & 2,184 \\
\hline CG &, 064 & 112 & ,030 & ,569 & ,570 & ,432 & 2,314 \\
\hline AFV &,- 092 & ,098 &,- 041 &,- 938 & ,349 & ,597 & 1,674 \\
\hline AGU & ,330 & 127 & 158 & 2,602 & ,009 & ,318 & 3,140 \\
\hline $\mathrm{AH}$ &,- 097 & 111 &,- 052 &,- 873 & 383 & 334 & 2,996 \\
\hline AEM & ,084 & ,072 & ,054 & 1,169 & ,243 & ,542 & 1,844 \\
\hline AGN & ,397 & 108 & 193 & 3,658 & ,000 & 420 & 2,379 \\
\hline
\end{tabular}

MI: Marka İmajı, FI: Firma İmajı, FG: Firma Güveni, CG: Çalışan Güveni, AFV: Algılanan Fiziksel Varlıklar, AGU: Algılanan Güvenilirlik, AH: Algılanan Heveslilik, AEM: Algılanan Empati, AGN: Algılanan Güven

\subsubsection{Marka Algııının Müşteri Tatminine Etkisinde Algılanan Değerin Aracılık Rolüne İlişkin Analiz Sonuçları}

Algılanan değerin, marka algısının müşteri tatminine etkisinde aracılık rolünün etkisi, iki yöntemle test edilmiştir. B-K yöntemine göre aracılık testi için gerekli koşulları gösteren Tablo 11'deki ilk üç denklem anlamlı çıktığından, son denklemi veren tablo değerine bakıldığında, marka algısının müşteri tatminine etkisini gösteren regresyon katsayısının 0,903'ten 0,791'e düştüğü görülmüştür.

Tablo 11: Marka Algısının Müşteri Tatminine Etkisinde Algılanan Değerin Aracılık Rolünün Testine ilişkin Regresyon Modelleri

\begin{tabular}{|l|c|c|c|c|c|}
\hline Bağımsız Değişkenler & Bağımlı Değişken & F & p & $\begin{array}{c}\text { Marka AlgıSı } \\
\text { Regresyon Katsayısı }\end{array}$ & p \\
\hline Marka Algısı & Müşteri Tatmini & 716,393 & 0,000 & 0,903 & 0,000 \\
\hline Marka Algısı & Algılanan Değer & 350,357 & 0.000 & 0.726 & 0.000 \\
\hline Algılanan Değer & Müşteri Tatmini & 248,383 & 0.000 & & \\
\hline Marka Algısı, Algılanan Değer & Müşteri Tatmini & 381,342 & 0.000 & 0.791 & 0.000 \\
\hline
\end{tabular}


B-K (Baron - Kenny) yönteminde algılanan değerin kısmi aracılık etkisi ortaya çıkmış olmakla birlikte, ayrıca doğrulama amaçlı yapılan Hayes Testi, $\mathrm{p}$ değeri için bir aralık vermekte ve bu aralıkta 0 değerinin bulunmaması gerekir. Hayes testinin sonuçlarına göre çıkan değer aralığı 0,0079 - 0,1843 olup koşul sağlanmaktadır. Buna göre H2 hipotezi desteklenmiştir.

\subsubsection{Marka Algısının Müşteri Tatminine Etkisinde, Algılanan Değerin Kolaylaştırıcılık Rolüne ilişkin Analiz Sonuçları}

Algılanan değerin marka algısının müşteri tatminine etkisinde kolaylaştırıcılık rolünü ortaya koymak üzere, marka algısı ve algılanan değerin birlikte etkisini ifade eden iki değerin çarpımı ile bir değişken (MAAD) elde edilmiştir. Tablo 12'deki sonuçlara göre; marka algısının algılanan değerle bileşimini gösteren MAAD değişkeni anlamlı çıktığından algılanan değerin, marka algısının müşteri tatminine etkisini kolaylaştırıcı role sahip olduğu görülmektedir. H3 hipotezi kabul edilmiştir.

Tablo 12: Marka Algısının Müşteri Tatminine Etkisinde Algılanan Değerin Kolaylaştırıcılık Rolüne iliş̧kin Çoklu Regresyon Modeli

\begin{tabular}{|c|c|c|c|c|c|c|c|}
\hline Model & \multicolumn{2}{|c|}{ Katsayılar } & \multirow{2}{*}{$\begin{array}{l}\text { Standardize } \\
\text { Katsayılar } \\
\text { Beta } \\
\end{array}$} & \multirow[b]{2}{*}{$\mathbf{t}$} & \multirow[b]{2}{*}{ p } & \multicolumn{2}{|c|}{ Eş Doğrusallık } \\
\hline 1 & B & Standart Hata & & & & Tolerans & VIF \\
\hline Sabit & 0,781 & 0,145 & & 5,403 & 0,000 & & \\
\hline MA & 0,669 & 0,060 & 0,518 & 11,170 & 0,000 & 0,308 & 3,244 \\
\hline MAAD & 0,039 & 0,008 & 0,217 & 4,686 & 0,000 & 0,308 & 3,244 \\
\hline
\end{tabular}

\subsubsection{Marka Algısının Müşteri Bağlılığına Etkisinde, Müşteri Tatmininin Aracılık Rolüne illişkin Analiz Sonuçları}

Müşteri tatmininin, marka algısının müşteri bağıılığına etkisinde B-K Yöntemine göre aracılık rolünün koşullarını gösteren Tablo 13'deki ilk üç denklem anlamlı çıktığından, son denklemi veren tablo değerine bakıldığında, marka algısının müşteri bağıı̆̆ına etkisini gösteren regresyon katsayısının 0,943'ten 0,531'e düştüğü görülmüştür.

Tablo 13: Marka Algısının Müşteri Bağııı̆ına Etkisinde Müşteri Tatmininin Aracılık Rolünün Testine illişkin Regresyon Modelleri

\begin{tabular}{|l|l|c|c|c|c|}
\hline Bağımsız Değişkenler & $\begin{array}{l}\text { Bağımlı } \\
\text { Değişken }\end{array}$ & F & p & \multicolumn{1}{c|}{$\begin{array}{c}\text { Marka Algısı } \\
\text { Regresyon Katsayısı }\end{array}$} & p \\
\hline Marka Algısı & Müşteri Bağlıı̆ıı & 658.440 & 0.000 & 0.943 & 0.000 \\
\hline Marka Algısı & Müşteri Tatmini & 716.393 & 0.000 & 0.903 & 0.000 \\
\hline Müşteri Tatmini & Müşteri Bağıı̆ı̆ı & 706.706 & 0.000 & & \\
\hline Marka Algısı, Müşteri Tatmini & Müşteri Bağıı̆ığı & 478.461 & 0.000 & 0.531 & 0.000 \\
\hline
\end{tabular}

Yukarıdaki analiz sonuçları ve ayrıca doğrulama amaçlı yapılan Hayes Testine göre dolaylı etkide p’nin aralığı olan 0,3233 - 0,5122 arasında 0 değeri olmadığından müşteri tatmininin kısmi aracılık etkisi doğrulanmış olup, H4 hipotezi desteklenmiştir.

\subsubsection{Algılanan Hizmet Kalitesinin Müşteri Tatminine Etkisinde Algılanan Değerin Aracılık Rolüne iliş̧in Analiz Sonuçları}

B-K (Baron - Kenny) Yöntemine göre algılanan değerin, algılanan hizmet kalitesinin müşteri tatminine etkisinde aracılık rolünün koşullarını gösteren Tablo 14'deki ilk üç denklem anlamlı çıktığından, son denklemi veren tablo değerine bakıldığında, algılanan hizmet kalitesinin müşteri tatminine etkisini gösteren regresyon katsayısının 0,832'den 0,673'e düştüğü görülmüştür.

Tablo 14: Algılanan Hizmet Kalitesinin Müşteri Tatminine Etkisinde, Algılanan Değerin Aracilık Rolü

\begin{tabular}{|l|l|c|c|c|c|}
\hline Bağımsız Değişkenler & Bağımlı Değişken & F & p & $\begin{array}{c}\text { Algılanan Hizmet } \\
\text { Kalitesi Regresyon } \\
\text { Katsayısı }\end{array}$ & p \\
\hline Algılanan Hizmet Kalitesi & Müşteri Tatmini & 486.216 & 0.000 & 0.832 & 0.000 \\
\hline Algılanan Hizmet Kalitesi & Algılanan Değer & 351,784 & 0.000 & & \\
\hline Algılanan Değer & Müşteri Tatmini & 248,383 & 0.000 & & \\
\hline $\begin{array}{l}\text { Algılanan Hizmet Kalitesi, } \\
\text { Algılanan Değer }\end{array}$ & Müşteri Tatmini & 275,614 & 0.000 & 0,673 & 0.000 \\
\hline
\end{tabular}


Yukarıda çıkan analiz sonuçları ve doğrulama amaçlı yapılan Hayes Testi sonuçlarına göre p'ye ilişkin değer aralığında 0 değeri bulunmamaktadır. Buna göre algılanan değerin aracılık rolü doğrulanmış olup H5 hipotezi kabul edilmiştir.

\subsubsection{Algılanan Hizmet Kalitesinin Müşteri Tatminine Etkisinde Algılanan Değerin Kolaylaştırıcılık Rolüne illişkin Analiz}

Algılanan değerin, algılanan hizmet kalitesinin müşteri tatminine etkisinde kolaylaştırıcı rolünü ortaya koymak üzere, algılanan hizmet kalitesi ve algılanan değerin birlikte etkisini ifade eden iki değerin çarpımı ile bir değişken elde edilmiştir. Tablo $15^{\prime}$ deki sonuçlara göre; algılanan değeri içeren algılanan hizmet kalitesini veren kolaylaştırıcı değişken AHKAD, modelde anlamlı çıktığından $\mathrm{H} 6$ hipotezi kabul edilmiştir.

Tablo 15: Algılanan Hizmet Kalitesinin Müşteri Tatminine Etkisinde, Algılanan Değerin Kolaylaştırıcılık Rolüne ilişsin Çoklu Regresyon Modeli

\begin{tabular}{|c|c|c|c|c|c|c|c|}
\hline Model & \multicolumn{2}{|c|}{ Katsayılar } & \multirow{2}{*}{$\begin{array}{c}\begin{array}{c}\text { Standardize } \\
\text { Katsayılar }\end{array} \\
\text { Beta }\end{array}$} & \multirow[b]{2}{*}{$\mathbf{t}$} & \multirow[b]{2}{*}{$\mathbf{p}$} & \multicolumn{2}{|c|}{ Eş Doğrusallık } \\
\hline 1 & B & Standart Hata & & & & Tolerans & VIF \\
\hline Sabit & ,978 & 147 & & 6,658 & ,000 & & \\
\hline AHK & ,730 & , 047 & ,561 & 15,687 & ,000 & ,654 & 1,529 \\
\hline AHKAD & ,010 & ,004 & ,080 & 2,224 & ,026 & ,654 & 1,529 \\
\hline
\end{tabular}

3.3.7. Algılanan Hizmet Kalitesinin Müşteri Bağlılığına Etkisinde, Müşteri Tatmininin Aracılık Rolüne illişkin Analiz Sonuçları

B-K (Baron - Kenny) Yöntemine göre müşteri tatmininin, algılanan hizmet kalitesinin müşteri bağlılığına etkisinde aracılık rolünün koşullarını gösteren Tablo 16'daki ilk üç denklem anlamlı çıktığından, son denklemi veren tablo değerine bakıldığında, algılanan hizmet kalitesinin müşteri bağlılığına etkisini gösteren regresyon katsayısının 0,912'den 0,483'e düştüğü görülmüştür.

Tablo 16: Algılanan Hizmet Kalitesinin Müşteri Bağlılığına Etkisinde Müşteri Tatmininin Aracılık Rolü

\begin{tabular}{|l|l|c|c|c|c|}
\hline Bağımsız Değişkenler & Bağımlı Değişken & F & $\mathbf{p}$ & $\begin{array}{c}\text { Algılanan Hizmet } \\
\text { Kalitesi Regresyon } \\
\text { Katsayısı }\end{array}$ & $\mathbf{p}$ \\
\hline Algılanan Hizmet Kalitesi & Müşteri Bağlıı̆ı̆ & 530.222 & 0.000 & 0.912 & 0.000 \\
\hline Algılanan Hizmet Kalitesi & Müşteri Tatmini & 486.216 & 0.000 & 0,832 & 0.000 \\
\hline Müşteri Tatmini & Müşteri Bağlı̆ı̆ı & 706.706 & 0.000 & 0,744 & 0.000 \\
\hline $\begin{array}{l}\text { Algılanan Hizmet Kalitesi, } \\
\text { Müşteri Tatmini }\end{array}$ & Müşteri Bağlı̆ı̆ı & 468.187 & 0.000 & 0.483 & 0.000 \\
\hline
\end{tabular}

B-K Yöntemine göre elde edilen analiz sonuçları ve doğrulama amaçlı yapılan Hayes Testine göre, dolaylı etkide $p$ aralığı içinde 0 değeri bulunmadığından müşteri tatminin aracılık etkisi doğrulanmıştır. Başka bir anlatımla, algılanan hizmet kalitesinin müşteri bağııığına etkisinde, müşteri tatmininin aracılık rolü olduğu saptanmıştır. Buradan çıkan sonuçla H7 hipotezi kabul edilmiştir.

\subsubsection{Marka Algısı ve Algılanan Hizmet Kalitesinin Müşteri Bağlıığına Etkisi}

Dört bileşenden oluşan “Marka Algısı” ile beş bileşenden oluşan “Algılanan Hizmet Kalitesi” değişkenlerinin Müşteri Bağlılı̆ı'na etkisi, çoklu regresyon analizi ile yapılmıştır. İlk aşamada marka algısı ve algılanan hizmet kalitesi değişkenleri, bileşenlerinin toplamı olarak değerlenerek analize alınmıştır. Tablo 18'e göre model \%1 önem derecesinde anlamlı çıkmıştır. Tablo 17’ye göre; Marka Algısı ve Algılanan Hizmet Kalitesi arasındaki korelasyon katsayısı $R=0,700$ olup, ilişkinin kuvvetli olduğu anlaşılmaktadır. Nitekim iki değişken müşteri bağlıı̆ının yüzde 48,8'ini açıklamaktadır. Modelin katsayıları ve eş doğrusallık değerleri Tablo 19 'da gösterilmiştir. Bu sonuçlara göre $\mathrm{H} 8$ hipotezi kabul edilmiştir. 
Tablo 17: Marka Algısı ve Algılanan Hizmet Kalitesinin Müşteri Bağlılı̆ına Etkisine İlişkin Çoklu Regresyon Model İstatistikleri

\begin{tabular}{|c|l|l|l|l|}
\hline Model & $\mathbf{R}$ & $\mathbf{R}^{\mathbf{2}}$ & Düzeltilmiş $\mathbf{R}^{\mathbf{2}}$ & Tahminin Standart Hatası \\
\hline 1 &, 700 &, 490 &, 488 &, 66823 \\
\hline
\end{tabular}

Tablo 18: Marka Algısı İle Algılanan Hizmet Kalitesinin Müşteri Bağlılığına Etkisine i̇lişkin Çoklu Regresyon Modeli ANOVA Sonuçları

\begin{tabular}{|l|c|c|c|c|c|}
\hline Model & $\begin{array}{c}\text { Karelerin } \\
\text { Toplamı }\end{array}$ & $\begin{array}{c}\text { Serbestlik } \\
\text { Derecesi }\end{array}$ & $\begin{array}{c}\text { Karelerin } \\
\text { Ortalaması }\end{array}$ & $\mathbf{F}$ & $\mathbf{p}$ \\
\hline Regresyon & 320,913 & 2 & 160,456 & 359,343 &, 000 \\
Artık & 334,448 & 749 &, 447 & & \\
Toplam & 655,361 & 751 & & & \\
\hline
\end{tabular}

Tablo 19: Marka Algısı ve Algılanan Hizmet Kalitesinin Müşteri Bağıılığına Etkisine ilişkin Çoklu Regresyon Modeli Katsayıları

\begin{tabular}{|c|c|c|c|c|c|c|c|}
\hline \multirow[t]{2}{*}{ Model } & \multicolumn{2}{|c|}{$\begin{array}{c}\text { Standardize Olmayan } \\
\text { Katsayılar }\end{array}$} & \multirow{2}{*}{\begin{tabular}{|c|}
$\begin{array}{c}\text { Standardize } \\
\text { Katsayılar }\end{array}$ \\
Beta \\
\end{tabular}} & \multirow[b]{2}{*}{$\mathbf{t}$} & \multirow[b]{2}{*}{$\mathbf{p}$} & \multicolumn{2}{|c|}{ Eş Doğrusallık } \\
\hline & B & $\begin{array}{c}\text { Standart } \\
\text { Hata }\end{array}$ & & & & Tolerans & VIF \\
\hline Sabit &,- 138 & 146 & &,- 945 & 345 & & \\
\hline MA & ,644 & ,055 & ,466 & 11,770 & ,000 & ,435 & 2,298 \\
\hline $\mathrm{AHK}$ & , 387 & ,055 & 279 & 7,044 & ,000 & ,435 & 2,298 \\
\hline
\end{tabular}

3.4. Kavramsal Modelde Yer Alan Değişkenler Arasındaki iliş̧kilerin Cevaplayıcıların Demografik Özelliklerine Göre Farklılık Analizi Sonuçları

\subsubsection{Marka Algısı ve Algılanan Hizmet Kalitesinin Algılanan Değere Etkisinin Farklılık Analizleri Sonuçları}

Marka algısı ve algılanan hizmet kalitesinin algılanan değere etkisinin yaş gruplarına göre farklılığı test edilmiştir. Tablo 20 'de görüleceği üzere; 18-30, 31-40 ve 41-50 yaş gruplarındaki modeller \%1 önem derecesinde anlamlı iken; 51 ve üstü yaş grubunda ise $\% 5$ önem derecesinde anlamlıdır. Tablo 20’ye göre; 18-30, 31-40 ve 41-50 yaş gruplarında Marka Algısı ve Algılanan Hizmet Kalitesinin Algılanan Değere etkisinin var olduğu; ancak bu etkinin 31-40 yaş aralığında algılanan hizmet kalitesinde daha düşük $(0,271)$ iken; $41-50$ yaş grubunda ise daha yüksek $(0,576)$ olduğu görülmektedir.

Ayrıca, 51 ve üstü yaş grubunda da; marka algısının algılanan değere etkisinin olmadığı $(p=0,191)$, fakat algılanan hizmet kalitesinde bu etkinin anlamlı $(p=0,05)$ olduğu görülmektedir. Buradan çıkan sonuca göre, yaş grupları arasında farklılık olduğu görüldüğünden $\mathrm{H} 9$ hipotezi kabul edilmiştir.

Tablo 20: Marka Algısı ve Algılanan Hizmet Kalitesinin Algılanan Değere Etkisinin Yaş Gruplarına Göre Farklılık Analizi

\begin{tabular}{|l|c|c|c|c|c|c|}
\hline \multirow{2}{*}{ Yaş Grupları } & \multicolumn{2}{|c|}{ Model } & \multicolumn{2}{c|}{ Marka Algısı } & \multicolumn{2}{c|}{$\begin{array}{c}\text { Algılanan } \\
\text { Hizmet Kalitesi }\end{array}$} \\
\cline { 2 - 7 } & $\mathbf{F}$ & $\mathbf{p}$ & $\mathbf{B}$ & $\mathbf{p}$ & $\mathbf{B}$ & $\mathbf{p}$ \\
\hline $18-30$ & 106,316 & 0,000 & 0,367 & 0,000 & 0,473 & 0,000 \\
\hline $31-40$ & 41,956 & 0,000 & 0,477 & 0,000 & 0,271 & 0,017 \\
\hline $41-50$ & 68,739 & 0,000 & 0,479 & 0,001 & 0,576 & 0,000 \\
\hline 51 ve üstü & 2,014 & 0,141 & $-1,474$ & 0,191 & 2,383 & 0,050 \\
\hline
\end{tabular}

Marka Algısı ve Algılanan Hizmet Kalitesinin Algılanan Değere etkisinin cinsiyete göre regresyon modelleri \%1 önem derecesinde anlamlı olup, Marka Algısı ve Algılanan Hizmet Kalitesinin, Algılanan Değere etkisinde; marka algısının etkisi, erkeklerde anlamsız $(p=0,837)$ iken; algılanan hizmet kalitesinde ise erkeklerde etki, kadınlara göre daha yüksektir $(B=0,799)$. Dolayısıyla, kadın-erkek arasında fark bulunduğundan $\mathrm{H} 10$ hipotezi kabul edilmiştir. 
Tablo 21: Marka Algısı ve Algılanan Hizmet Kalitesinin Algılanan Değere Etkisinin Cinsiyete Göre Farklılık Analizi

\begin{tabular}{|l|c|c|c|c|c|c|}
\hline \multirow{2}{*}{ Cinsiyet } & \multicolumn{2}{|c|}{} & \multicolumn{2}{c|}{ Marka Algısı } & \multicolumn{2}{c|}{$\begin{array}{c}\text { Algılanan } \\
\text { Hizmet Kalitesi }\end{array}$} \\
\cline { 2 - 7 } & Fodel & p & B & p & B & p \\
\hline Kadın & 98,779 & 0,000 & 0,484 & 0,000 & 0,354 & 0,000 \\
\hline Erkek & 17,906 & 0,000 & 0,043 & 0,837 & 0,799 & 0,000 \\
\hline
\end{tabular}

Tablo 22'de görüleceği üzere, Marka Algısı ve Algılanan Hizmet Kalitesinin Algılanan Değere etkisinin öğrenim durumuna göre regresyon modelleri \%1 önem derecesinde anlamlı çıkmıştır. Marka Algısı ve Algılanan Hizmet Kalitesinin, Algılanan Değere etkisinin öğrenim durumuna göre analizi incelendiğinde; tüm cevaplayıcılarda bu etkinin var olduğu, bunun yanında Algılanan Hizmet Kalitesinin Algılanan Değere etkisini gösteren regresyon katsayısının lise düzeyinde eğitim görenlerde $(0,610)$, üniversite ve üstü öğrenin gruplarında $(0,615)$ olması sebebiyle söz konusu etki daha yüksek iken; aynı gruplarda marka algısının etki düzeyinin (lise 0,301 , üniversite ve üstü 0,199 ) diğer gruplara göre daha düşük olduğu görülmektedir. Dolayısıyla öğrenim grupları arasında fark olduğundan $\mathrm{H} 11$ hipotezi kabul edilmiştir.

Tablo 22: Marka Algısı ve Algılanan Hizmet Kalitesinin Algılanan Değere Etkisinin Öğrenim Durumuna Göre Farklılık Analizi

\begin{tabular}{|l|c|c|c|c|c|c|}
\hline \multirow{2}{*}{\begin{tabular}{l}
\multirow{2}{*}{$\begin{array}{l}\text { Öğrenim } \\
\text { Durumu }\end{array}$} \\
\cline { 2 - 7 }
\end{tabular}} & $\mathbf{F}$ & \multicolumn{2}{c|}{ Marka Algısı } & \multicolumn{2}{c|}{$\begin{array}{c}\text { Algılanan } \\
\text { Hizmet Kalitesi }\end{array}$} \\
\hline İlköğretim & 8,983 & $\mathbf{p}$ & $\mathbf{p}$ & $\mathbf{p}$ & $\mathbf{B}$ & $\mathbf{p}$ \\
\hline Lise & 86,281 & 0,000 & 0,416 & 0,142 & 0,354 & 0,228 \\
\hline $\begin{array}{l}\text { Üniversite } \\
\text { ve Üstü }\end{array}$ & 20,754 & 0,000 & 0,199 & 0,276 & 0,615 & 0,001 \\
\hline
\end{tabular}

\subsubsection{Algılanan Değerin Müşteri Tatminine Etkisinin Farklılık Analizleri Sonuçları}

Algılanan Değerin, müşteri tatminine etkisini yaş gruplarına göre analiz ettiğimizde; model, 18-50 yaş arasındaki yaş gruplarında yüzde 1 önem derecesinde anlamlı iken; 51 ve üstü yaş grubunda ise \%5 önem derecesinde anlamlıdır. Analizde yer alan değişken algılanan değerin müşteri tatminine etkisinin varlığı, 18-30 ve 31-40 yaş gruplarında, $41-50$ yaş grubuna göre nispeten, 51 ve üstü yaş grubuna göre ise oldukça yüksek düzeydedir. Çünkü söz konusu etkinin, 51 ve üzeri yaş grubunda yok denilecek kadar az olduğu analizdeki regresyon katsayısından $(0,006)$ görülmektedir. Sonuç olarak, Algılanan Değerin müşteri tatminine etkisinde yaş grupları arasında fark bulunduğundan $\mathrm{H} 12$ hipotezi kabul edilmiştir.

Tablo 23: Algılanan Değerin Müşteri Tatminine Etkisinin Yaş Gruplarına Göre Farklılık Analizi

\begin{tabular}{|l|c|c|c|c|}
\hline & Model & & \multicolumn{2}{c|}{ Algılanan Değer } \\
\hline Yas Grupları & $\mathbf{F}$ & $\mathbf{p}$ & $\mathbf{B}$ & $\mathbf{p}$ \\
\hline $18-30$ & 142,804 & 0,000 & 0,547 & 0,000 \\
\hline $31-40$ & 63,957 & 0,000 & 0,514 & 0,000 \\
\hline $41-50$ & 62,311 & 0,000 & 0,498 & 0,000 \\
\hline 51 ve üstü & 0,068 & 0,795 & 0,006 & 0,795 \\
\hline
\end{tabular}

Model yüzde 1 önem derecesinde anlamlı olup, Algılanan Değerin müşteri tatminine etkisini cinsiyete göre değerlendirdiğimizde, kadın-erkek olarak her iki grupta da bu etki vardır; ancak analizde çıkan regresyon katsayısına göre $(0,101)$ söz konusu etkinin erkek cevaplayıcılarda anlamlı düzeyde olmadığı görülmektedir. Sonuç olarak cinsiyet grupları arasında fark olmadığından H13 hipotezi reddedilmiştir. 
Tablo 24: Algılanan Değerin Müşteri Tatminine Etkisinin Cinsiyete Göre Farklılık Analizi

\begin{tabular}{|l|c|c|c|c|}
\hline & \multicolumn{2}{|c|}{ Model } & \multicolumn{2}{c|}{ Algılanan Değer } \\
\hline Cinsiyet & F & p & B & p \\
\hline Kadın & 100,628 & 0,000 & 0,480 & 0,000 \\
\hline Erkek & 22,019 & 0,000 & 0,101 & 0,000 \\
\hline
\end{tabular}

Algılanan Değerin müşteri tatminine etkisini öğrenim durumuna göre analiz ettiğimizde; model yüzde 1 önem derecesinde anlamlı çıkmış olup, Algılanan Değerin müşteri tatminine etkisinin her öğrenim grubunda var olduğu; ancak bu etkinin lise düzeyindeki öğrenim grubunda biraz daha yüksek; üniversite ve üstü grupta ise daha düşük olduğu görülmektedir. Çıkan sonuca göre; Algılanan Değerin müşteri tatminine etkisi tüm öğrenim gruplarında var olduğu için $\mathrm{H} 14$ hipotezi reddedilmiştir.

Tablo 25: Algılanan Değerin Müşteri Tatminine Etkisinin Öğrenim Durumuna Göre Farklılık Analizi

\begin{tabular}{|l|c|c|c|c|}
\hline & \multicolumn{2}{|c|}{ Model } & \multicolumn{2}{c|}{ Algllanan Değer } \\
\hline Öğrenim Durumu & F & p & B & p \\
\hline Illköğretim & 6,433 & 0,015 & 0,313 & 0,015 \\
\hline Lise & 86,516 & 0,000 & 0,564 & 0,000 \\
\hline Üniversite ve Üstü & 28,019 & 0,000 & 0,107 & 0,000 \\
\hline
\end{tabular}

\subsubsection{Müşteri Tatmininin Müşteri Bağlılığına Etkisinin Farklılık Analizleri Sonuçları}

Müşteri Tatmininin müşteri bağıılı̆ına etkisini yaş gruplarına göre analiz ettiğimizde; model yüzde 1 önem derecesinde anlamlı çıkmıştır. Tablo 26 'daki regresyon katsayılarından da görüleceği üzere, tüm yaş gruplarında bu etkinin varlığının yüksek olduğu görülmektedir. Dolayısıyla yaş grupları arasında fark olmadığından H15 hipotezi reddedilmiştir.

Tablo 26: Müşteri Tatmininin Müşteri Bağlılığına Etkisinin Yaş Gruplarına Göre Farklılık Analizi

\begin{tabular}{|l|c|c|c|c|}
\hline & \multicolumn{2}{|c|}{ Model } & \multicolumn{2}{c|}{ Müşteri Tatmini } \\
\hline Yas Grupları & F & p & B & p \\
\hline $18-30$ & 323,638 & 0.000 & 0,701 & 0.000 \\
\hline $31-40$ & 192,135 & 0.000 & 0,789 & 0.000 \\
\hline $41-50$ & 114,694 & 0.000 & 0,841 & 0.000 \\
\hline 51 ve üstü & 96,776 & 0.000 & 0,769 & 0.000 \\
\hline
\end{tabular}

Müşteri Tatminin müşteri bağlılığına etkisini cinsiyet gruplarına göre analiz ettiğimizde; Model yüzde 1 önem derecesinde anlamlı çıkmış olup, Müşteri Tatminin müşteri bağlılığına etkisinin her iki cinsiyet grubunda da yüksek düzeyde var olduğu Tablo 27 'deki regresyon katsayılarından da görülmektedir. Dolayısıyla cinsiyet grupları arasında fark olmadığından H16 hipotezi reddedilmiştir.

Tablo 27: Müşteri Tatmininin Müşteri Bağlılığına Etkisinin Cinsiyete Göre Farklılık Analizi

\begin{tabular}{|l|c|c|c|c|}
\hline & \multicolumn{2}{|c|}{ Model } & \multicolumn{2}{c|}{ Müşteri Tatmini } \\
\hline Cinsiyet & F & p & B & p \\
\hline Kadın & 296.869 & 0.000 & 0,735 & 0.000 \\
\hline Erkek & 407.046 & 0.000 & 0,749 & 0.000 \\
\hline
\end{tabular}

Müşteri Tatminin müşteri bağııı̆̆ına etkisinin öğrenim gruplarına göre analizini gösteren Tablo 28'e baktığımızda, model yüzde 1 önem derecesinde anlamlı çıkmış olup, Müşteri Tatmininin müşteri bağlılı̆ına etkisinin tüm öğrenim gruplarında yüksek düzeyde var olduğu, analizdeki regresyon katsayılarından da görülmektedir. Dolayısıyla öğrenim grupları arasında fark bulunmadığından H17 hipotezi reddedilmiştir. 
Tablo 28: Müşteri Tatmininin Müşteri Bağıııı̆ına Etkisinin Öğrenim Durumuna Göre Farklılık Analizi

\begin{tabular}{|l|c|c|c|c|}
\hline & \multicolumn{2}{|c|}{ Model } & \multicolumn{2}{c|}{ Müşteri Tatmini } \\
\hline Öğrenim Durumu & $\mathbf{F}$ & $\mathbf{p}$ & $\mathbf{B}$ & $\mathbf{p}$ \\
\hline İlköğretim & 61,183 & 0.000 & 0,761 & 0.000 \\
\hline Lise & 234,952 & 0.000 & 0,777 & 0.000 \\
\hline Üniversite ve Üstü & 425,634 & 0.000 & 0,731 & 0.000 \\
\hline
\end{tabular}

\section{ARAŞTIRMA BULGULARI}

Araştırmanın amacında belirtilen hedefler ile kavramsal modelde yer alan değişkenler ve ilişkileri ışığında yapılan analizler sonucu elde edilen bulgular şu şekilde özetlenebilir:

- Marka algısı ve algılanan hizmet kalitesi, müşterinin algıladığı değeri ve müşteri bağlılığını olumlu yönde etkilemektedir $(\mathrm{H} 1, \mathrm{H} 8)$. Ancak, analizde çıkan sonuçların detaylarına bakıldığında, marka algısı ve algılanan hizmet kalitesi ile algılanan değer arasındaki ilişkinin zayıf olduğu ve algılanan hizmet kalitesinin algılanan değere etkisinin, marka algısına göre daha yüksek olduğu görülmüştür. Buna karşın, marka algısı ve algılanan hizmet kalitesinin müşteri bağılığına olan etkisinin ise, yüksek düzeyde olduğu belirlenmiştir.

- Marka algısının müşteri tatminine etkisinde, algılanan değerin kısmi aracılık rolü desteklenmiştir (H2).

- Bununla birlikte, algılanan değerin, marka algısının müşteri tatminine etkisinde kolaylaştırıcı role sahip olduğu görülmüştür $(\mathrm{H} 3)$.

- Ayrıca, marka algısının müşteri bağlılığına etkisinde, müşteri tatmininin kısmi aracılık rolü doğrulanmıştır (H4).

- Bununla birlikte, algılanan hizmet kalitesinin müşteri tatminine etkisinde, algılanan değerin aracılık rolü doğrulanmıştır (H5). Ayrıca, kolaylaştırıcılık etkisinin olduğu da tespit edilmiştir (H6).

- Son olarak, algılanan hizmet kalitesinin müşteri bağlılığına etkisinde, müşteri tatmininin aracılık rolü olduğu saptanmıştır (H7)

Marka algısının etkilerine ilişkin sonuçlar, Brodie vd.'nin (2009:345) “marka algısı - sadakat süreci” üzerine yaptığı araştırma sonuçları, Kandampully ve Suhartanto'nun (2000:346) "turizm sektöründe imajın müşteri bağlılığı ile pozitif bir ilişkide olduğu, müşterilerin geri satın alma ve tavsiye etme kararlarının arkasındaki temel belirleyici faktör olduğu" na yönelik bulguları ve hizmet sektöründe müşteri bağlıığının oluşumunda kurumsal imajın rolünü inceleyen Andreassen ve Lindestad'in (1997:21), imajın bağııık üzerinde hem doğrudan hem de dolaylı etkisine dair bulguları ve ayrıca, Mudambi, vd.'nin (1997: 441) yaptıkları çalışmada, marka algısının müşteri değerini olumlu etkilediğine dair bulguları ile uyumludur.

Algılanan hizmet kalitesinin algılanan değere etkisiyle ilgili sonuçlar ise, benzer çalışmalar yapan Cronin vd. (1997:383-384), Sweeney vd., (1999:99), Parasuraman ve Grewal (2000: 168-174), Sweeney ve Soutar (2001:203-220), Cretu ve Brodie'nin (2007: 236) bulgularıyla uyumludur. Ayrıca, algılanan hizmet kalitesinin müşteri bağlılığına olan etkisi de; Kheng vd., (2010:62), Rai ve Medha, (2013:153), Amin, (2016:280), Velosa vd., (2018:497) ve Arora ve Narula'nın (2018:33) araştırma bulgularıyla uyumludur.

Bununla birlikte algılanan değer, müşteri tatmini ve müşteri bağılığı ilişkisine yönelik elde edilen sonuçlara göre; marka algısının müşteri tatminine etkisinde, algılanan değerin aracılık rolü doğrulanmıştır. Bu bulgu, Lai vd.'nin (2009:984) “imajın, algılanan değer aracılığıyla müşteri tatmini üzerinde dolaylı bir etkiye sahip olduğu” yönündeki bulgularıyla uyumludur. Ayrıca, algılanan değerin, marka algısının müşteri tatminine etkisinde kolaylaştırıcı role sahip olduğu görülmüştür. Benzer şekilde, algılanan hizmet kalitesinin müşteri tatminine etkisinde, algılanan değerin aracılık rolünün ve kolaylaştırıcılık etkisinin olduğu tespit edilmiştir.

Ayrıca, marka algısı ve algılanan hizmet kalitesinin müşteri bağlılığına etkisinde de, müşteri tatmininin aracılık rolü olduğu saptanmıştır. Marka algısına dair sonuç, Brodie vd.'nin (2009:345) “marka algısının müşteri bağıılı̆ına doğrudan bir etkisinin olmadığı, bunun yerine, müşteri değeri aracılı̆̆ıyla gerçekleştiği” yönündeki bulgusu ile benzerdir. Algılanan hizmet kalitesinin bağlılığa etkisinde müşteri tatmininin rolüne ilişkin sonuçlar ise, Kheng vd.'nin (2010:62) bankacılık hizmet kalitesinin müşteri bağlılığı üzerine etkisinin incelendiği çalışma sonuçları, Minh ve Huu'nun (2016:110) bireysel bankacılık müşterileri arasında hizmet kalitesi - müşteri bağlılığı sürecine yönelik yaptıkları araştırma sonuçları ile Caruana'nın (2002:821), müşteri tatmininin aracılık 
rolünü üstlenerek hizmet kalitesinin bağlılık üzerindeki etkisini incelediği sonuçlar ve benzer biçimde Mosahab vd.'nin (2010:72) elde ettiği bulgular ile uyumludur.

Bu sonuçlar, algılanan değer - müşteri tatmini ve müşteri bağlılı̆ı sürecinde, bankaların birer marka olarak imajlarının ve sundukları hizmetlerin kalitesinin müşteride yarattığı değer algısı ile tatmin duygusunun bağılığa etkilerini göstermektedir. Söz konusu sonuçlar, her alanda rekabetin yoğun olarak yaşandığı günümüz iş dünyasında bankaların yeni müşteri kazanmak ve mevcut müşterilerini elde tutmak için uygulayacakları pazarlama stratejilerine ışık tutar niteliktedir. Bununla birlikte, banka yöneticilerinin pazarlama faaliyetlerinde özellikle müşterilerin demografik yapılarını dikkate almalarının, sundukları hizmetlerin arzu edilen doğru sonuçları yaratması bakımından önemli olduğu dikkate alınmalıdır. Örneğin, elde edilen sonuçlara göre; 51 ve üstü yaş grubunda, algılanan hizmet kalitesinin algılanan değere etkisi, diğer gruplara göre oldukça yüksek iken; marka algısının, algılanan değere etkisinin olmadığının tespit edilmesi, bu grupta yer alan müşterilerin değer algısında, hizmet kalitesinin marka algısına göre daha çok önem arz ettiği şeklinde yorumlanabilir.

Aynı şekilde, cinsiyete göre yapılan analiz sonucunda da, marka algısı ve algılanan hizmet kalitesinin algılanan değere etkisinde; marka algısının etkisi, erkeklerde kadınlara göre oldukça düşük; fakat algılanan hizmet kalitesinde ise daha yüksek çıkması, erkeklerde hizmet kalitesinin, kadınlarda ise marka algııının daha önemli olduğu şeklinde değerlenebilir.

Dikkat çeken bir diğer demografik sonuç ise öğrenim düzeyiyle ilgilidir. İlköğretim mezunu grubundaki katılımcılarda, marka algısının algılanan değere etkisinin, diğer öğrenim gruplarına göre daha yüksek, fakat algılanan hizmet kalitesinin etkisinin daha düşük çıkması; diğer taraftan lise mezunu ile üniversite ve üstü öğrenim gören gruplarda ise tam tersi olarak algılanan hizmet kalitesinin algılanan değere etkisinin yüksek, fakat marka algısının etkisinin daha düşük olması, "öğrenim düzeyi yükseldikçe marka algısının algılanan değere etkisinin azaldığı ya da hizmet kalitesinin etkisinin daha önemli olduğu" şeklinde yorumlanabilir.

Benzer şekilde algılanan değerin, müşteri tatminine etkisinde de demografik sonuçlar önem arz etmektedir. Örneğin, 51 yaş ve üzeri grupta algılanan değerin tatmine olan etkisinin azaldı̆̆ı, kadın katılımcılarda söz konusu etkinin erkeklere göre daha yüksek olduğu, öğrenim düzeyine göre ise, üniversite ve üstü mezun seviyesindeki kişilerde daha düşük olduğu sonucu, "öğrenim düzeyi ve yaş yükseldikçe değer algısının tatmine olan etkisi azalmaktadır" şeklinde yorumlanabilir. Ayrıca, "kadınların değer atfettikleri şeylerden mutlu oldukları" yorumu da çıkarılabilir. Bununla birlikte, müşteri tatmininin müşteri bağlılığına etkisinin her üç demografik özelliğe göre de yüksek düzeyde olması, "tatmin, müşteri bağlılı̆ının en önemli göstergelerinden biridir" şeklinde yorumlanabilir.

\section{SONUÇ ve ÖNERILER}

Araştırma kapsamında elde edilen sonuçlar; akademik alandaki araştırmacılara marka algısı ve algılanan hizmet kalitesi fenomenlerinin, müşteri değeri ve müşteri bağlılığı sürecindeki etkilerinin ortaya koyduğu teorik bulgular ile banka yöneticileri ve diğer uygulayıcılara kendi faaliyet alanlarında sürdürülebilir rekabet avantajı sağlamak için, müşteriye gerçekten değer katan ve müşteri bağıılığını artıran faktörlerin neler olduğunu bilmeleri konusunda oldukça önemli bilgiler sunmaktadır.

İşletmelerin yaşamlarını karlı bir biçimde sürdürebilmeleri, doğru yönetim stratejileri ile mümkündür. Strateji, "nasıl" sorusunun cevabıdır. Ulaşılmak istenilen hedefe giden pek çok alternatif yöntem olabilir. En düşük maliyetle en uygun kaynakların kullanılarak en yüksek çıktıyı sağlayacak en uygun alternatifin bulunması, bir yönetsel başarıdır. Ancak, bu yönetsel başarının en önemli koşulu, sürdürülebilir olmasıdır. Kısa vadeli hiçbir başarı geleceği garanti etmemektedir. Bu nedenle, işletmelerin stratejilerini belirlerken uzun vadeli ve sürdürülebilir performanslara odaklanmaları, günümüz rekabet koşullarının yadsınamaz bir gerçeğidir. Bu gerçeğin temelini ise "değer" oluşturmaktadır. Burada sözü edilen değer, yalnızca işletme performansının bir sonucu olarak yaratılan "hissedar değeri" demek değildir; aynı zamanda bu değerin yaratılma sürecine dahil olan tüm paydaşlar için de yaratılan değerdir (Khalifa, 2004:646). Ancak, tüm bu değerlerin kaynağında "müşteri değeri" vardır (Grönroos, 2000:9). Bu amaçla, yönetsel stratejinin gerçekleşebilmesi için, önce "müşteri değeri" nin yaratılması, dolayısıyla tüm işletme faaliyetlerinde müşterinin merkeze alınması gereklidir (Holbrook, 1994:22).

Birer ticari işletme olan bankaların günümüz rekabet koşullarında sürdürülebilir performans elde edebilmeleri, üstün müşteri değeri yaratacak faaliyetlerde bulunarak yeni müşteriler kazanmaları ve mevcut müşterilerini de elde tutmalarıyla mümkün olacaktır. Gelişen teknolojik bilginin bankacılık uygulamalarında kullanılması, kaliteli ürün ve hizmetlerin çoğalmasına ve dolayısıyla sektörde rekabetin artmasına neden olmaktadır. Artan bu rekabet ortamında, bankaların kurumsal imajları ve sundukları hizmetler ile üstün müşteri değeri yaratarak memnun ve bağlı müşterilerini çoğaltmaları, önemli bir sürdürülebilirlik stratejisi haline gelmiştir. 
Bu bağlamda banka yöneticilerinin sürdürülebilir rekabet avantajı yaratmak için, müşteriye gerçekten değer katan ve müşteri bağlıığını artıran faktörlerin neler olduğunu bilmeleri oldukça önemlidir. Bu amaçla, müşteri değer algısı ve bağlılığına etki eden marka algısı (marka imajı, işletme imajı, işletmeye güven ve çalışana güven) unsurlarına dikkat etmeleri ve sundukları hizmetlerin kalite unsurlarının (somut varlıklar, güvenilirlik, heveslilik, güvence, empati) müşteride yaratacağı değer algısı ile müşteri tatminine önem vermeleri yerinde olacaktır.

\section{REFERENCES}

Al-Tit, A. A. (2015). The Effect of Service and Food Quality on Customer Satisfaction and Hence Customer Retention. Asian Social Science, 11(23), 129-140.

Amin, M. (2016). Internet banking service quality and its implication on e-customer satisfaction and e-customer loyalty. The International Journal of Bank Marketing, 34(3), 280-306.

Andreassen, T. W. ve Lindestad, B. (1997). Customer Loyalty and Complex Services: The Impact of Corporete Image on quality, customer satisfaction and Loyalty for Customers with Varying Degrees of Service Expertise. International Journal of Service Industry Management, 8(4), 133.

Arora, P., Narula, S. (2018). Linkages Between Service Quality, Customer Satisfaction and Customer Loyalty: A Literature Review. IUP Journal of Marketing Management, 17(4), 31-53.

Boksberger, P. E. ve Melsen, L. (2011). Perceived value: a critical examination of definitions, concepts and measures for the service industry. Journal of Services Marketing, 25(3), 229-240.

Brodie, R. J., Whittome, J. R. M., Brush, G. J. (2009). Investigating the service brand: A customer value perspective. Journal of Business Research, 62(3), 345-355.

Caruana, A. (2002). Service Loyalty: The Effects of Service Quality and The Mediating Role of Customer Satisfaction. European Journal of Marketing, 36(7), 811-828.

Cretu, A. E. ve Brodie, R. J. (2007). The influence of brand image and company reputation where manufacturers market to small firms: A customer value perspective. Industrial Marketing Management, 36(2), 230-240.

Cronin, J. J., Brady, M. K., Brand, R. R., Hightower, R. ve Shemwell, D. J. (1997). A-Cross Sectional Test of the Effect and Concepualization of Service Value. The Journal of Service Marketing, 11(6), 375-391.

Dick, A. S. ve Basu, K. (1994). Customer Loyalty: Toward an Integrated Conceptual Framework. Journal of The Academy of Marketing Science. 22(2), 99-113.

El- Adly, M. I. (2018). Modelling the relationship between hotel perceived value, customer satisfaction, and customer loyalty. Journal of Retailling and Consumer Services, Article in Press, xxx (xxxx) xxx-xxx

Grönroos, C. (1984). A Service Quality Model and its Marketing Implications. European Journal of Marketing, 18(4), 36-44.

Holbrook, M. B. (1994). The nature of customer value: an axiology of services in the consumption experience. New directions in theory and practice, 21(1), 21-71.

Kahneman, D. (2017). Hızlı ve Yavaş Düşünme (5. Baskı). (Çeviren, Ç. Deniztekin ve F. N. Deniztekin). İstanbul: Varlık Yayınları

Kandampully, J. ve Suhartanto, D. (2000). Customer Loyalty in the Hotel Industry: The Role of Customer Satisfaction and Image. International Journal of Contemporary Hospitality Management, 12(6), 346-351.

Kapferer, J. N. (2008). The New Strategic Brand Management: Creating and Sustaining Brand Equity Long Term (4th Edition). London: Kogan Page Publishers

Khalifa, A. S. (2004). Customer Value: A Review of Recent Literature and an Integrative Configuration. Management Decision, 42(5), 645-666.

Kheng, L. L., Mahamad, O., Ramayah T. ve Mosahab, R. (2010). The Impact of Service Quality on Customer Loyalty: A Study of Banks in Penang, Malaysia. International Journal of Marketing Studies, 2(2), 57-66

Kotler, P. (1999). Marketing Management Millenium Edition (10th Edition). New Jersey: Prentice-Hall

Lai, F., Griffin, M., Babin, B. J. (2009). How quality, value, image, and satisfaction create loyalty at a Chinese telecom. Journal of Business Research $62(10), 980-986$.

Lenka, U., Suar, D., Mohapatra, P. K. J. (2009). Service Quality, Customer Satisfaction, and Customer Loyalty in Indian Commercial Banks. The Journal of Entrepreneurship, 18(1), 47-64. 
Mascarenhas, O. A., Kesavan, R., Bernacchi, M. (2006). Lasting Customer Loyalty: A Total Customer Experience Approach. Journal of Consumer Marketing, 23(7), 397-405.

Minh, N. V. ve Huu, N. H. (2016). The Relationship Between Service Quality, Customer Satisfaction and Customer Loyalty: An Investigation in Vietnamese Retail Banking Sector. Journal of Competitiveness, 8(2), 103-116.

Mosahab, R., Mahamad, O., Ramayah, T. (2010). Service Quality, Customer Satisfaction and Loyalty: A Test of Mediation. International Business Research, 3(4), 72-80

Mudambi, S. MD., Doyle, P, Wong, V. (1997). Exploration of branding in industrial markets. Industrial Marketing Management, $26,433-446$.

Parasuraman A. P. ve Grewal, D. (2000). The Impact of Technology on the Quality-Value-Loyalty Chain: A Research Agenda. Journal of the Academy of Marketing Science, 28(1), 168-174.

Parasuraman, A., Zeithaml, V. A., Berry, L. L. (1985). A Conceptual Model of Service Quality and Its Implications for Future Research. Journal Of Marketing, 49, 41-50.

Parasuraman, A., Zeithaml, V. A., Berry, L. L. (1988). SERVQUAL: A Multiple-Item Scale for Measuring Consumer Perceptions Of Service Quality. Journal of Retailing, 64(1), 12-40.

Patterson, P. G. ve Spreng, R. A. (1997). Modelling the relationship between perceived value, satisfaction and repurchase intentions in a businessto-business, services context: an empirical examination. International Journal of Service Industry Management, 8(5), 414-434.

Rai, A. K. ve Medha, S. (2013). The Antecedents of Customer Loyalty: An Empirical Investigation in Life Insurance Context. Journal of Competitiveness, 5(2), 139-163.

Roig, J. C. F., García, J. S., Tena, M. A. M. (2009). Perceived value and customer loyalty in financial services. The Service Industries Journal, 29(6), 775-789.

Sheth, J. N., DePaul, B. I. N., Gross, B. L. (1991). Why We Buy What We Buy: A Theory of Consumption Values. Journal of Business Research, 22(2), $159-170$.

Sweeney, J. C. ve Soutar, G. N. (2001). Consumer perceived value: The development of a multiple item scale. Journal of Retailing, Vol. 77(2), 203220.

Sweeney, J. C., Soutar, G. N., Johnson, L. W. (1999). The Role of Perceived Risk in the Quality-Value Relationship: A Study in a Retail Environment. Journal of Retailing, 75(1), 77-105.

Wood, L. M. C. (2000). Brands and brand equity: definition and management. Management Decision 38(9), 662-669.

Woodruff, R. B. (1997). Customer Value: The Next Source for Competitive Advantage. Journal of the Academy of Marketing Science. 25(2), 139153.

Veloso, C. M., Magueta, D., Ribeiro, H. ve Alves, S. R. (April 19-20, 2018). The Links Between Service Quality, Brand Image, Customer Satisfaction and Loyalty in The Retail Industry. 28th International Scientific Conference on Economic and Social Development Economic and Social Development: Book of Proceedings. Varazdin Development and Entrepreneurship Agency. 497-511.

Yang, Z., Peterson, R. T. (2004). Customer Perceived Value, Satisfaction, and Loyalty: The Role of Switching Costs. Psychology \& Marketing, 21(10), 799-822.

Yüksel, G. "Bilişsel Öğrenme Kuramı” (2014). (Ed.) Sevil Filiz Büyükalan, Öğrenme Öğretme Kuram ve Yaklaşımları (3. Baskı). Ankara: Pegem Akademi

Yükselen, C. (2017). Pazarlama (illkeler - Yönetim - Örnek Olaylar) (14. Baskı). Ankara: Detay Yayıncılık

Zeithaml, V. A. (1988). Consumer Perceptions of Price, Quality, and Value: A Means-End Model and Synthesis of Evidence. Journal of Marketing, $52(3), 2-22$.

Grönroos, C. (2000). Service Management and Marketing: A Customer Relationship Management Approach, 2nd ed. Chichester: Wiley. https://archive.org/details/servicemanagemen0000gron/page/10/mode/2up (Erişim Tarihi: 30.08.2020)

Heskett, J. L., Jones, T. O., Loveman, G. W., Sasser, W. E. ve Schlesinger, L. A. (2008). Putting the Service - Profit Chain to Work. Harvard Business Review. 1-23. https://hbr.org/2008/07/putting-the-service-profit-chain-to-work (Erişim Tarihi: 08.12.2020)

Sağlam, M. F. (2019). Markanın Tarihi, Dünden Bugüne Marka Kavramı. BrandingTurkiye.www.brandingturkiye.com (Erişim tarihi: 05.05.2020) 